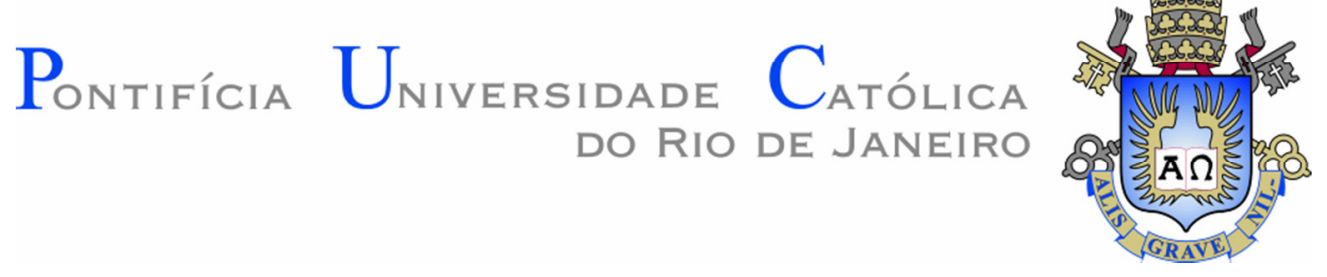

Gustavo Eletherio Hooper Braga

O papel das margens e diferenciais na formação do

Preço do Petróleo

Dissertação de Mestrado

Dissertação apresentada ao Programa de Pósgraduação em Administração de Empresas da PUC-Rio como requisito parcial para obtenção do grau de Mestre em Administração de Empresas.

Orientador: Prof. Antônio Carlos Figueiredo

Rio de Janeiro

Abril de 2018 


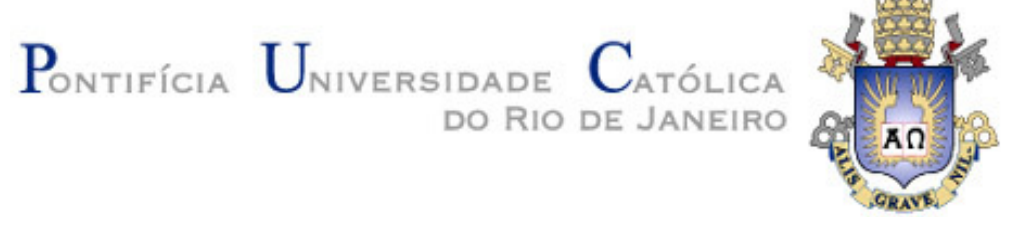

Gustavo Eletherio Hooper Braga

\title{
O papel das margens e diferenciais na formação do Preço do Petróleo
}

Dissertação apresentada como requisito parcial para obtenção do grau de Mestre pelo Programa de PósGraduação em Administração de Empresas da PUC-Rio. Aprovada pela Comissão Examinadora abaixo assinada.

\author{
Prof. Antônio Carlos Figueiredo Pinto \\ Orientador \\ Departamento de Administração - PUC-Rio \\ Prof. Leonardo Lima Gomes \\ Departamento de Administração - PUC-Rio
}

Prof. Marcelo Cabús KIötzle Departamento de Administração - PUC-Rio

Prof. Augusto Cesar Pinheiro da Silva Vice-Decano de Pós-Graduação do CCS - PUC-Rio 
Todos os direitos reservados. É proibida a reprodução total ou parcial do trabalho sem autorização da universidade, do autor e do orientador.

\section{Gustavo Eletherio Hooper Braga}

Graduado em economia pela Universidade Federal do Rio de Janeiro com extensão acadêmica na Universidade de Salamanca na Espanha e especialização em Finanças pelo Coppead. Possui mais de 10 anos de experiência em empresas multinacionais e brasileiras de grande porte atuando principalmente nas áreas de trading, estratégia e desenvolvimento de negócios na indústria de Petróleo, Gás e Biocombustíveis. Atua como consultor independente paralelamente à carreira corporativa.

Ficha Catalográfica

Braga, Gustavo Eletherio Hooper

O papel das margens e diferenciais na formação do preço do petróleo / Gustavo Eletherio Hooper Braga ; orientador: Antonio Carlos Figueiredo. - 2018.

$58 \mathrm{f}$. : il. color. ; $30 \mathrm{~cm}$

Dissertação (mestrado)-Pontifícia Universidade Católica do Rio de Janeiro, Departamento de Administração, 2018.

Inclui bibliografia

1. Administração - Teses. 2. Preço mercado. 3. Petróleo Brent. 4. Comércio internacional referências. I. Pinto, Antonio Carlos Figueiredo. II. Pontifícia Universidade Católica do Rio de Janeiro. Departamento de Administração. III. Título. 
A minha esposa Tatiana e filhos Joaquim e Julia. 


\section{Agradecimentos}

À minha esposa Tatiana, fundamental na formação da nossa família. Em especial nos últimos dois anos em que nasceram nossos filhos, Joaquim e Julia. Sem seu apoio este trabalho não seria possível.

Ao meu Avô Ítalo (em memória), por ter sido meu primeiro professor e ídolo. Fonte de força para seguir em frente sempre que as pedras surgiram em meu caminho.

Aos meus pais, pelo amor e dedicação implacáveis à minha educação e formação.

Ao meu orientador, professor Antônio Carlos Figueiredo pelo apoio desde as ideias iniciais que geraram este trabalho.

Ao professor Helder Queiroz pelas conversas e estímulos durante a concepção das ideias contidas neste trabalho. Seu conhecimento e experiência foram fundamentais para seguir firmemente em frente.

Aos meus chefes e colegas de trabalho na Sinochem Brasil pela paciência e suporte nas horas críticas de dedicação ao mestrado.

Aos professores do IAG, pela dedicação ao ensino e ideias compartilhadas.

Aos meus colegas de turma sem os quais toda a trajetória seria bem menos interessante.

À PUC-Rio, pelo ambiente acolhedor e rico que proporciona aos alunos.

À Deus. 


\section{Resumo}

Braga, Gustavo Eletherio Hooper; Figueiredo, Antônio Carlos. O papel das margens e diferenciais na formação do Preço do Petróleo. Rio de Janeiro, 2018. 58p. Dissertação de Mestrado - Departamento de Administração, Pontifícia Universidade Católica do Rio de Janeiro.

Neste trabalho será descrito o Índice de Pressão criado a partir da conjunção da margem de refino e dos diferenciais de preços dos petróleos físicos. Este índice tem por função revelar possíveis descolamentos entre o preço do benchmark ICE Brent e os diversos petróleos físicos negociados. Como os benchmarks sofrem influência de diversos outros fatores econômicos, e não somente dos dados correntes de oferta e demanda, de tempos em tempos, movimentos anormais ocorrem. Espera-se também, que tentativas de manipulação dos benchmarks via operações no mercado futuro tornem-se explícitas a partir da observação do Índice de Pressão. Sua definição busca demonstrar qual o papel dos diferenciais na identificação das condições correntes de equilíbrio do mercado físico com relação ao mercado financeiro. Na primeira parte do trabalho, há uma breve descrição do mercado e sua evolução histórica. Ainda no início do trabalho, agentes chave serão apresentados e seus papéis descritos. No capítulo 3, será apresentado o mercado do Mar do Norte e a mecânica de funcionamento dos seus principais benchmarks. Uma atenção especial será dada aos complexos instrumentos que conectam as dimensões físicas e financeiras do mercado. No capítulo 4 será descrita como o funcionamento do mercado se dá a partir das negociações baseadas em diferenciais ou spreads. No capítulo final, será introduzido o Índice de Pressão. O foco deste trabalho será na definição do Índice, bem como, na aplicação da teoria num estudo de caso do petróleo colombiano Castilla. Desta forma, podemos definir este trabalho como um estudo de caso qualitativo.

\section{Palavras- chave}

Preço mercado; Petróleo Brent; comércio internacional referências. 


\section{Abstract}

Braga, Gustavo Eletherio Hooper; Figueiredo, Antônio Carlos (Advisor). The whole of the margins and differentials on the Oil market price. Rio de Janeiro, 2018. 58p. Dissertação de Mestrado - Departamento de Administração, Pontifícia Universidade Católica do Rio de Janeiro.

In this work the Pressure Index, created from the conjunction of the refining margin and the price differentials of the physical oils, will be described. This index is intended to reveal possible mismatches between the ICE Brent benchmark price and the various traded physical oils. As the benchmarks are influenced by several other economic factors, not only from the current supply and demand data, from time to time, abnormal movements occur. It is also expected that attempts to manipulate the benchmarks will become explicit. The Pressure Index seeks to demonstrate the role of the differentials in the identification of the current equilibrium conditions of the physical market in relation to the financial market. On the beginning, there is a brief description of the market and its historical evolution. Key agents will be introduced and their roles described. In Chapter 3, the North Sea market and the mechanics of its main benchmarks will be presented. Attention will be paid to the complex instruments that connect the physical and financial dimensions of the market. In Chapter 4 it will be described how the operation of the market takes place from the negotiations based on differentials or spreads. In the final chapter, the Pressure Index will be introduced. The focus of this work will be on the definition of the Index as well as on the application of the theory in a case study of the Colombian petroleum Castilla. In this way, we can define this work as a qualitative case study.

\section{Keywords}

Price Market; oil brent; trading marker benchmark. 


\section{Sumário}

1. Introdução 10

2. Precificação de Petróleo 12

2.1. O Mercado Global de Petróleo 12

2.2. História da Precificação de Petróleo 13

2.2.1. A Era do "Posted Price" 14

2.2.2. A Ascenção dos Preços Administrados da OPEP 14

2.3. O Sistema de Precificação pelo Mercado e Formulas
de Preço

2.4. Agências de Reporte de Preços (PRAs - Price Reporting
Agencies)

3. O Brent e o Mercado do Mar do Norte 22

3.1. A Dimensão Física 23

3.2. A Dimensão Financeira 24

3.3. O Processo de Descoberta de Preço no Mar do Norte 27

3.4. As Conexões entre os Mercados Físicos e Financeiros 28

4. Um Mercado de Diferenciais (Spreads) 31

4.1. Margem de Refino e Crack Spreads 31

4.2. Os Diferenciais de Preço do Petróleo 38

5. As Distorções do mercado e suas Reversões: O Índice de Pressão

5.1. A Combinação dos Diferenciais 44

5.2. O índice de Pressão 48

6. Conclusão 56

7. Referências Bibliográficas 58 


\section{Lista de gráficos}

Gráfico 1: Diferenciais de Preço para o Dated Brent 18

Gráfico 2: Diferenciais de Preço para o Dated Brent 30

Gráfico 3: Margens de Refino 33

Gráfico 4: Rendimentos por grupo de Produto 34

Gráfico 5: Diferencial do Óleo Combustível 36

Gráfico 6: Crack Spread $\quad 37$

Gráfico 7: Margens Históricas $\quad 37$

Gráfico 8: Diferenciais de Petróleos Pesados 39

Gráfico 9: Diferencial de Petróleo leve e pesado 40

Gráfico 10: Estoques Comerciais EUA e Diferencial de um

petróleo pesado $\quad 41$

Gráfico 11: Estoques Comerciais EUA e Diferencial de um petróleo pesado 42

Gráfico 12: Diferencial histórico Castilla 43

Gráfico 13: Preço do lce Brent sobrevalorizado 45

Gráfico 14: Volume total de posições em aberto ICE Brent 46

Gráfico 15: Preço do Ice Brent subvalorizado 47

Gráfico 16: Volume total de posições em aberto ICE Brent 47

Gráfico 17: Representação esquemática do Índice de Pressão 48

Gráfico 18: Representação esquemática dos valores do Índice de Pressão 49

Gráfico 19: índice de Pressão abaixo da Média 49

Gráfico 20: índice de Pressão acima da média 50

Gráfico 21: Comportamento Histórico do índice de Pressão 51

Gráfico 22: Volume nas Reservas Estratégicas do EUA 52

Gráfico 23: Reversão do índice de pressão para a média e aumento do preço do ICE Brent 54

Gráfico 24: Queda dos estoques comerciais de Petróleo dos EUA e aumento do Preço do ICE Brent 


\section{1 \\ Introdução}

A importância do petróleo na dinâmica econômica do mundo moderno é indiscutível. Somente o fato de que, todos os produtos comercializados hoje em dia têm como insumo, direta ou indiretamente, um produto derivado de petróleo, já é suficiente para demonstrar sua importância vital.

Tal importância, portanto não se reflete na atenção dada pela população aos mercados desta commodity. Todos os dias alguns agentes espalhados pelo globo fazem negócios que podem ter repercussão direta na vida da maioria dos seres que habitam este planeta. Podemos separar o mercado de petróleo em basicamente dois tipos: $\mathrm{O}$ mercado financeiro, que negocia instrumentos derivativos e o mercado físico, onde os agentes negociam o petróleo efetivamente produzido. Ambos os mercados possuem dinâmicas próprias, mas, por diversos meios, se conectam e tendem a convergir no longo prazo.

$\mathrm{Na}$ primeira parte do trabalho, capítulo 2, há uma breve descrição do mercado e sua evolução histórica. Como os mercados evoluíram e o papel da geopolítica neste processo. Ainda no início do trabalho, agentes chave do mercado serão apresentados e seus papéis descritos.

Em seguida, no capítulo 3, será apresentado o mercado do Mar do Norte e a mecânica de funcionamento dos seus principais benchmarks. O foco será dado nesta região por atualmente ser considerada a que produz os benchmarks considerados globais, ou seja, os preços formados nesta região são responsáveis pela precificação de negócios por todo o globo. Uma atenção especial será dada aos complexos instrumentos que conectam as dimensões físicas e financeiras deste mercado.

No capítulo 4 será descrita como o funcionamento do mercado se dá a partir das negociações baseadas em diferenciais ou spreads. Os únicos preços absolutos considerados são os dos benchmarks, sendo os outros tipos de petróleo negociados a partir de diferenciais para estes benchmarks. 
No capítulo final, será descrito o Índice de Pressão criado a partir da conjunção dos dois principais diferenciais existentes, a margem de refino e os diferenciais de preços dos petróleos físicos. Este índice tem por função revelar possíveis descolamentos entre o preço do benchmark ICE Brent e os diversos petróleos físicos negociados. Como os benchmarks sofrem influência de diversos outros fatores econômicos, e não somente dos dados correntes de oferta e demanda, de tempos em tempos, movimentos anormais ocorrem. Além de flutuações determinadas pelas expectativas do mercado espera-se também que tentativas de manipulação dos benchmarks via operações no mercado futuro tornem-se explícitas a partir da observação do Índice de Pressão. Sua definição busca demonstrar qual o papel dos diferenciais na identificação das condições correntes de equilíbrio do mercado físico com relação ao mercado financeiro.

Por se tratar da introdução de diversos dados sobre o mercado de petróleo e de uma nova perspectiva de análise, o foco deste trabalho será na definição do Índice, bem como, na aplicação da teoria num estudo de caso do petróleo colombiano Castilla. Desta forma, podemos definir este trabalho como um estudo de caso qualitativo que abre um leque de oportunidades de análises quantitativas futuras. 


\section{2 \\ Precificação de petróleo}

\section{1.}

\section{O mercado global de petróleo}

O petróleo é um dos produtos mais negociados no mundo e, junto com sua importância como mercadoria, há um mercado de alta complexidade que mescla camadas físicas e financeiras. A visão de que o petróleo adquiriu características de ativos financeiros, como ações e títulos, está ganhando aceitação entre muitos observadores (FATTOUH, 2011). De fato, há muitos laços que unem as camadas em questão sendo a principal delas os instrumentos derivativos negociados em bolsa.

O volume diário de petróleo consumido no mundo gira em torno de 98 milhões de barris sendo que o volume negociado dos dois principais contratos futuros do mundo, Brent e WTI, gira em torno de 2.000 milhões de barris diários, considerando ainda que aproximadamente metade dos barris consumidos são negociados no mercado internacional, podemos dizer que o mercado financeiro supera o mercado físico em aproximadamente 50 vezes (MORGAN STANLEY, 2018).

Os fundamentos do mercado de petróleo são observados na sua camada física, quanto de petróleo é produzido, consumido, armazenado, transportado e negociado de comum acordo entre diversas partes. Como em qualquer mercado as forças de oferta e demanda deveriam agir de forma a fechar possíveis arbitragens fazendo que as camadas físicas e financeiras convergissem num preço comum, a história, porém, é mais complexa. Os fundamentos correntes nunca são conhecidos com certeza e o fluxo de informações não é instantâneo e estas informações podem ser objeto de revisão futura, sendo que os dados mais atuais não necessariamente são os mais confiáveis (FATTOUH, 2011). 
O modo como o "petróleo" até então está sendo tratado neste trabalho leva o leitor a crer que há homogeneidade neste produto, porém há muitos tipos específicos de petróleo. A principal variação diz respeito as qualidades físicas como densidade, enxofre, acidez, etc. Além disto há diferenças quanto a logística ou como o petróleo é transportado até seu destino final, sendo isto chave também para a determinação do valor de um grade específico.

Quando se fala simplesmente no "preço do petróleo" a referência para tal expressão é um dos benchmarks ou petróleo de referência existentes no mundo, sendo os mais famosos o Brent e o West Texas Intermediate, conhecido pela sua sigla, WTI. A partir destas referências a maior parte dos outros tipos de petróleo são negociados.

O comércio internacional é parte vital da indústria de petróleo, dada a distribuição desigual entre países produtores e consumidores. Tal característica gera implicações econômicas e geopolíticas que talvez nenhum outro produto tenha capacidade de gerar com tal magnitude. No campo econômico o preço do petróleo pode influenciar o crescimento, inflação, distribuição de renda, investimento, gastos públicos, balança comercial, taxas de câmbio, juros ou, para resumir, basicamente tudo o que compreende o estudo da macroeconomia. Estimativas mostram que o setor de produção de petróleo responde por cerca de $3 \%$ do PIB global e por aproximadamente $40 \%$ do déficit comercial dos Estados Unidos da América (MIAO, 2017). As implicações econômicas já seriam suficientes para determinar sua importância geopolítica, porém o petróleo tem uma outra característica que confere protagonismo vital para si, seu uso militar, sendo seus produtos usados como principal fonte combustível para forças armadas em torno do globo.

\section{2.}

\section{História da precificação de petróleo}

De acordo com Fattouh (2011) o sistema de preços de petróleo atual não pode ser entendido de forma isolada. Ele emergiu de mudanças na política global, estruturas econômicas, mudanças no balanço de poder e transformações políticas que fundamentalmente mudaram a estrutura do mercado e de sua cadeia de suprimentos. 


\subsection{1.}

\section{A era do "Posted Price"}

Seguindo a linha de tempo de Fattouh (2011) a precificação de petróleo foi dominada até meados dos anos 1950 por grandes companhias de petróleo conhecidas como sete irmãs ou Majors. Cada uma das sete irmãs possuía uma estrutura integrada verticalmente sendo responsáveis pela produção, refino e comercialização dos produtos de Petróleo. Estima-se que em 1950 estas empresas controlavam $85 \%$ da produção de petróleo fora do Canadá, EUA, União Soviética e China (DANIELSEN, 1982). O sistema de posted prices, ou preços de petróleo de referência para o pagamento de royalties (ANP, 2014), não refletiam as forças de oferta e demanda dos mercados. Desta forma, não exerciam uma função de alocação de recursos (MABRO, 1984) porém serviam como "piso" sob o qual as empresas petrolíferas não aceitariam precificar seu óleo (SEYMOUR, 1990).

Este sistema sofreu um abalo no fim dos anos 50 quando as empresas verticalizadas foram ameaçadas pela chegada das empresas de petróleo independentes. A Venezuela, por exemplo, concedeu áreas para algumas destas empresas e em 1965 as empresas independentes eram responsáveis por 15\% da produção da Venezuela (PARRA, 2004). Outros locais de produção crescente atraíram empresas independentes como a Líbia, Irã e Arábia Saudita. Apesar do crescimento do comércio internacional fora das mãos das sete irmãs, este mercado ainda era muito pequeno fazendo com que o equilíbrio continuasse a favor das Majors. Na verdade, o crescimento da competição no mercado levou a diminuição do posted price em 1959 e 1960 sendo que a criação da OPEP, organização dos países exportadores de petróleo nasceu de uma tentativa de prevenir a queda dos preços (SKEET, 1988).

\subsection{2.}

\section{A ascenção dos preços administrados da OPEP}

Ainda na linha de tempo proposta por Fattouh (2011) entre 1965 e 1973 viuse um aumento acelerado da demanda de petróleo do mundo. A maior parte da oferta para suprir tal aumento veio dos países membros da OPEP. A produção neste período praticamente dobrou de 14 milhões de barris por dia para 30 milhões de barris (FATTOUH, 2011). Este aumento de produção trouxe um aumento também do poder da organização perante as empresas produtoras de 
petróleo. Após uma negociação da Occidental na Líbia, que definiu um aumento dos posted prices todas as empresas daquele país passaram a pagar mais impostos e logo esta decisão levou a todos os membros da OPEP a aumentarem os posted prices numa reunião em Teerã em 1970.

Em setembro 1973 a OPEP decidiu revisar os termos do acordo de Teerã de 1970 e negociou um aumento significativo nos preços, não houve acordo com as companhias de petróleo e mais tarde em 16 de outubro do mesmo ano os seis países do golfo membros da OPEP, Irã, Arábia Saudita, Iraque, Kuwait, Qatar e Emirados Árabes Unidos anunciaram unilateralmente um aumento do cru Arabian Light de \$3,65 para \$5,119 dólares americanos por barril. E logo em seguida, em apoio aos países árabes, determinaram um corte de produção de 5\% e cortes adicionais mensais de 5\% até que os territórios palestinos invadidos por Israel fossem evacuados. Em dezembro deste mesmo ano os preços subiram novamente para $\$ 11,651$, mais importante do que atingir níveis sem precedentes de preços, a OPEP assegurou a mudança do balanço de poder, determinando pela primeira vez os posted prices (FATTOUH, 2011).

Este episódio popularmente conhecido como a primeira crise do petróleo, marcou um período de transformações na indústria. Países membros da OPEP passaram a exigir participação acionária nas concessões existentes sendo que alguns países optaram pela nacionalização completa dos recursos. Segundo Mabro (1984) este novo arranjo levou os países a introduzirem novos métodos de precificação uma vez que tendo participação acionária precisariam negociar o petróleo no mercado. O conceito de OSP, Oficial Selling Price, foi introduzido neste período e continua sendo utilizado por alguns exportadores até os dias de hoje.

A complexidade introduzida pelo sistema fez com que este arranjo tivesse vida curta pois com os posted price, OSPs e buyback prices um comprador poderia receber o mesmo barril com diferentes preços. Não havia transparência na precificação e com isso não havia mecanismo de convergência de preços. Em 1975 este sistema deixou de existir. 
O regime de preços administrados introduzido em 1974-75 representou uma mudança definitiva no balanço de poder em favor da OPEP, o conceito era de que o cru Árabe Leve seria a referência para os OSPS dos outros tipos de petróleo da região. A negociação era feita em termos diferenciais para o Árabe leve e os países tinham flexibilidade para determinar estes diferenciais. Este sistema se manteve assim até 1983 quando a OPEP optou por um sistema mais rígido de diferenciais que não obteve sucesso.

O declínio da demanda no meio dos anos 80 e o avanço da produção em países fora da OPEP representaram um desafio para o sistema de preços administrados. Com isto, produtores de fora do cartel começaram a oferecer uma variedade de tipos de petróleo com preços que variavam de acordo com as forças de mercado, no período de 1973 a 1985 a OPEP viu sua participação no mercado cair de $51 \%$ para $28 \%$ (FATTOUH 2011). As pressões sobre a OPEP aumentaram e conflitos internos acabaram surgindo. A Arábia Saudita, defensora do sistema de preços administrados, viu sua demanda cair de 10,2 milhões de barris por dia para 3,6 milhões de barris por dia de 1980 a 1985.

O abandono final dos preços administrados ocorreu em algum momento do ano de 1987 segundo Horsnell e Mabro (1993) com a adoção da formula de preços, isto abriu uma nova fase no sistema de preços de petróleo com o poder de preço saindo das mãos do cartel liderado pela Arábia Saudita para o mercado.

\section{3. \\ O sistema de precificação pelo mercado e formulas de preço}

Ainda na ordem cronológica proposta por Fattouh (2011), temos a evolução do sistema de precificação com a queda do sistema de preços administrados pela OPEP. A primeira empresa a adotar a formula de preços foi a mexicana PEMEX em 1986, em seguida a maioria dos países produtores seguiram a lógica de precificação por mercado e desde 1988 até hoje este método segue como dominante nos países exportadores de petróleo.

A base para a formação de preços à mercado começou a ser formada quando as concessões começaram a cair, nacionalizações foram feitas e novos produtores começaram a surgir fora da OPEP, isto fez com que o número de transações entre partes não relacionadas começasse a crescer. Este novo arranjo de mercado criou uma estrutura complexa em que os instrumentos financeiros passaram a ter papel 
primordial no dia a dia da indústria. Futuros, opções e outros instrumentos derivativos associados à comercialização eletrônica, revolucionaram a maneira como o mercado funciona, permitindo inclusive a participação de agentes não relacionados a cadeia produtiva de petróleo e o comércio durante $24 \mathrm{~h}$ do dia.

Em geral a venda de petróleo pode ser realizada no mercado spot ou via contrato de longo prazo. No caso da venda spot as particularidades logísticas do petróleo fazem com que haja um hiato de aproximadamente 45 a 60 dias entre a negociação e efetivo processamento numa refinaria. Isto faz com que o preço no momento da negociação seja diferente do preço no momento do carregamento do óleo. Em geral o preço acordado para estas vendas é definido no momento do carregamento com um diferencial para algum benchmark. Contratos de longo prazo diferem das vendas spot dado o número de carregamentos e prazo mais longo. Em geral acorda-se um número de cargas e um período no qual estas cargas serão entregues. A precificação em geral é feita com uma fórmula de preços que conecta a dinâmica de longo prazo a preços negociados no período de carregamento.

Como já exposto anteriormente o petróleo não é um produto homogêneo e suas características físicas fazem com que o seu preço varie de acordo com os produtos finais que são produzidos a partir do seu refino. As características principais avaliadas são a densidade e o conteúdo de enxofre. Em geral óleos menos densos ou mais leves tem um valor maior no mercado pois possuem uma quantidade maior de produtos de maior valor comercial. O enxofre por sua vez é um elemento indesejado nos produtos finais e sua concentração é inversamente proporcional ao preço do petróleo.

Estas diferenças de características fazem com que o petróleo possa ser negociado com um prêmio ou desconto com relação a um benchmark. Os diferencias podem variar ao longo do tempo dependendo das forças de mercado aplicadas ao comércio físico de petróleo e aos mercados subjacentes, como o de produtos derivados, frete, entre outros. No gráfico 1 abaixo, pode-se notar alguns exemplos em que os valores positivos representam um prêmio com relação ao benchmark Dated Brent e os valores negativos, descontos com relação ao mesmo benchmark. 


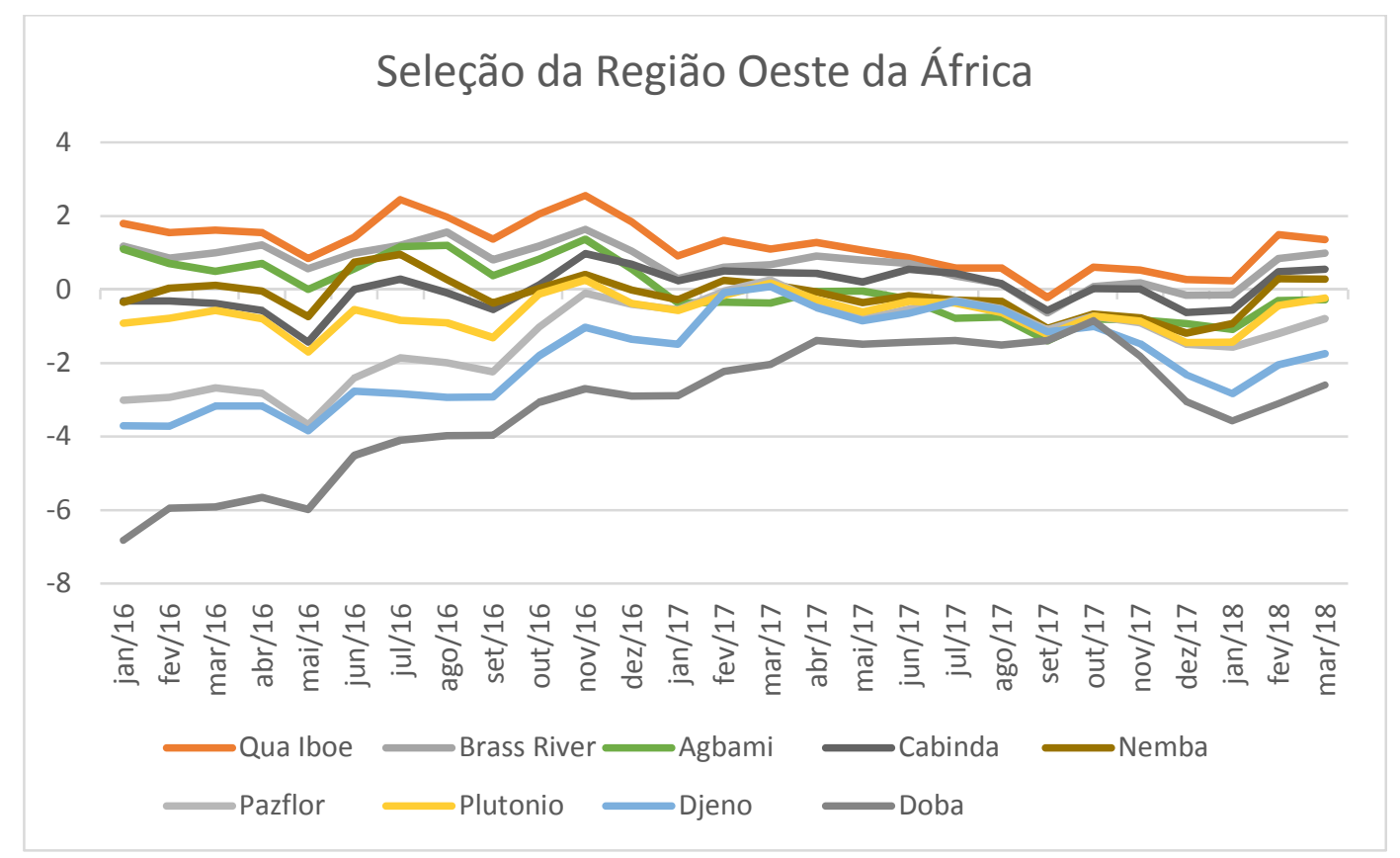

Gráfico 1: Diferenciais de Preço para o Dated Brent

Em geral os diferenciais refletem a situação do mercado no momento da negociação sem ter relação com o mercado no período do carregamento. Diferentemente do benchmark ou marcador escolhido como base, o qual tem seu valor considerado no momento do carregamento. Como exemplo temos que uma carga negociada em março tem seu diferencial fixado neste momento, porém somente no momento do carregamento é que se verifica o valor do marcador para determinar o preço final. Então se o diferencial é \$1,00 e o valor determinado do marcador no carregamento é $\$ 50,00$ a carga terá um preço final de $\$ 51.00$ por barril.

Há algumas maneiras de determinar os diferenciais de venda sendo as mais comuns uma fórmula de preço pré-negociada, negociação direta entre duas partes ou um leilão de venda. Todas estas maneiras trazem uma lógica de mercado que equilibra oferta e demanda sendo que se um diferencial é negociado muito fora desta lógica, forças de mercado agem rapidamente para corrigir via arbitragens entre locais diferentes de carregamento e venda. Desta forma o preço com que tipos de óleos semelhantes estão sendo negociados são muito importantes na definição do preço de venda de um petróleo específico. 
Há vários benchmarks que podem ser utilizados como base para aplicação do diferencial negociado e segundo Fattouh (2011) a escolha do petróleo de referência é o coração da fórmula de preços. Os benchmarks mais comuns são o WTI, Brent e Dubai. Esses benchmarks são chave para o sistema de precificação pois são utilizados por todos os agentes para precificar cargas tanto vendidas em contratos de longo prazo como para cargas denominadas spot. Além dos contratos de venda entre produtores e consumidores estes preços são utilizados pelas Bolsas de valores, bancos e governos para definir a tributação.

Dado o papel central que os benchmarks têm no mercado atual de petróleo, é importante salientar algumas características que logo serão exploradas em detalhe. A primeira característica é de que os preços não são observáveis em tempo real como ocorre com os contratos futuros. Esses preços são avaliados ou observados por agências de informação, sendo as mais importantes Platts e Argus (FATTOUH, 2011). Estas agências tem um papel importante de avaliar mercados opacos em que negociações entre partes não podem ser diretamente observadas pelos participantes do mercado. A metodologia utilizada pelas agências varia de mercado para mercado e os meios utilizados para as avaliações são os preços de negócios concluídos, ofertas de compra e venda, informações públicas e privadas de mercado e dados do mercado financeiro. Todos estes métodos são necessários pois nem sempre há negócios suficientes para determinar o valor, desta forma segundo Fattouh (2011) os preços avaliados por estas agências carregam um grau de subjetividade.

A segunda característica é que as agências não possuem o mesmo preço para o mesmo instrumento num determinado tempo. Como há metodologias variáveis que podem ser escolhidas por cada agência, seus resultados também variam.

Terceiro, a natureza dos benchmarks avaliados pelas agências de informação pode evoluir com o tempo. Por mais que o princípio se mantenha o mesmo, alguns detalhes podem mudar para fazer com os benchmarks continuem líquidos e confiáveis pelos agentes. Como exemplo podemos citar o Brent que agora possui não só o tradicional petróleo inglês, mas também outros, Forties, Oseberg, Ekofisk e Troll (BFOE). Neste caso fica claro que quando nos referimos ao "Brent" por exemplo estamos falando de um índice e não de um tipo específico de petróleo. 
Por último, chegamos no ponto central deste trabalho, que se refere ao desenvolvimento de mercados e instrumentos financeiros que fazem o link entre os diversos mercados financeiros e físicos e como estes instrumentos tem um papel central no processo de descoberta dos preços, o que no limite pode gerar distorções na formação de preços.

\section{4.}

\section{Agências de Reporte de Preços (PRAs - Price Reporting Agencies)}

As agências de reporte de preços são componentes fundamentais da indústria de petróleo atual. Os preços avaliados por estas agências estão na base da formação de preços para contratos de longo prazo, transações spot, ajuste de contratos futuros e outros instrumentos derivativos. O papel destas agências no fim é o de avaliar e divulgar os preços. Na tentativa de fazer isto, por vezes as agências entram no território da tomada de decisão que podem influenciar o mercado (FATTOUH, 2011). Tais decisões são tomadas em contato periódico com a indústria, com isto, acabam influenciando estratégias e comportamentos de agentes.

Segundo Barrett (2012), os mercados cresceram em termos de sofisticação e as $P R A$ s evoluíram de simples agências de informações para serem organizadores do mercado evitando portanto manipulações e erros. Esta tentativa leva a um distanciamento do mercado físico e financeiro, gerando distorções, algumas delas prolongadas. As dinâmicas entre os mercados acabam sendo diferentes, mas os laços que conectam os dois, pela maneira como o mercado está desenhado, se fortalecem a cada dia.

O papel das agências, mesmo no caso mais simples de reporte de uma transação realizada, está intimamente ligado a tomada de decisões e isto coloca um fator de individualidade, não só das agências em si, mas também dos seus editores e gerentes responsáveis pela construção e divulgação das informações. Isto leva a maior preocupação, o quão precisamente o mercado está precificando petróleo, ou o quão precisamente os fundamentos estão sendo refletidos nos preços negociados. 
As metodologias utilizadas pelas agências variam e, mesmo nos casos de avaliação mais simples, há divergência entre os dados divulgados. Em mercados líquidos estas diferenças não são preocupantes, mas em mercados menos líquidos a restrição de informação pode levar a distorções mais graves. Em períodos e mercados com poucos negócios as $P R A$ s dependem de informações diversas para fazer, de acordo com Fattouh (2011), "avaliações inteligentes”. Nestes casos, as agências irão olhar ofertas de compra e venda de outros mercados mais líquidos para estimar o valor. De fato, em mercados com poucos negócios, esta metodologia pode ser mais precisa pois expurga transações com a intenção de manipular o mercado.

Um ponto importante a destacar é que as agências sofrem pouca regulação oficial, sendo atribuído ao mercado o papel de julgar a fidúcia das informações. Há um incentivo à autorregulação. Se o mercado reconhecer que as informações não são precisas ou não refletem a dinâmica real, estas agências podem simplesmente deixar de existir. O contraponto a esta característica é que, dado que o mercado julga as ações e comportamentos, e que os participantes principais deste mercado são poucos, as agências de certa forma podem sofrer a influência destes agentes para seguir existindo. Mesmo em caso de disputa sobre o valor da avaliação feita, não há intervenção de nenhuma autoridade reguladora. Há um controle estrito sobre quais informações e quais empresas podem participar do mercado, sendo que as agências têm o poder de excluir informações que possam distorcer o preço divulgado. Por um lado, isto traz maturidade para o mercado, evitando agentes de baixa reputação e mal-intencionados, por outro limita o mercado a poucos participantes que possuem o poder de decidir indiretamente sobre negócios sendo travados em todo o mundo. 


\section{3 \\ O Brent e o Mercado do Mar do Norte}

O mercado do Brent no Mar do Norte tem um papel central no sistema de preços de petróleo. Desde os anos 80 os preços gerados nesta região servem de parâmetro para negócios em diversas regiões do globo. Segundo Fattouh (2011) cerca de $70 \%$ dos negócios globais de petróleo estão, direta ou indiretamente, conectados à este mercado.

No início o mercado compreendia somente o mercado spot do petróleo do tipo Brent, conhecido como Dated Brent e um mercado informal forward. Desde então o mercado cresceu em complexidade e uma série de instrumentos financeiros cresceram ao seu redor. Como colocado anteriormente, o mercado evoluiu para refletir as necessidades dos agentes.

Seguindo a linha de Fattouh (2011) uma série de atributos favoreceram a escolha do Brent como um marcador global. A localização geográfica próxima a grandes centros de refino e a logística marítima através de navios tanques que facilita a captura de arbitragens. Outro fator importante exposto por Fattouh (2011) é a questão tributária. Introduzida em 1979, favoreceu a negociação de cargas no mercado aberto pelos produtores ao invés de simplesmente verticalizar a cadeia de suprimentos. Em 1986 a produção no sistema do Brent era grande, em torno 885.000 barris por dia, garantindo assim consistência física para o comércio.

Havia outros centros importantes de negociação pelo mundo, alguns até com volume maior, porém este fator isolado não é suficiente para a criação de um referencial. Outros fatores introduzidos por Horsnell e Mabro (1993) são importantes para que haja um mercado verdadeiramente confiável. As questões legais e tributárias, número grande de participantes no mercado e infraestrutura de entrega física também são listadas como fundamentais para a supremacia do mercado do Mar do Norte sobre outras "praças" no mundo. 


\section{1.}

\section{A dimensão física}

Atualmente a dimensão física do Mar do Norte é formada por vários tipos de petróleo produzidos em diversos campos distintos, por países também distintos. Os principais tipos, porém, são Brent, Forties, Oseberg, Ekofisk e mais recentemente, Troll (Platts 2017), pois estes são os óleos utilizados na entrega física do contrato forward Cash BFOE.

A evolução do mercado começou com a conjunção do Brent com o Ninian em 1990, levando a criação do Brent Blend. Esta solução foi adotada para evitar manipulações pois a produção do Brent seguia em acelerado declínio. Em 2001, porém o declínio chegou ao chamado Brent Blend, e sua produção chegou a aproximadamente 400.000 barris por dia. Isto levou em 2002 a adoção do Forties e do Oseberg pela Platts. A inclusão destes dois novos grades não só levou ao aumento do volume e número de cargas, como também levou ao aumento do número de agentes participantes no mercado.

Em 2007 foi introduzido ao chamado BFO (Brent, Forties e Oseberg) o Ekofisk. Desta forma o volume de negociações e o número de agentes do mercado cresceu trazendo consigo mais maturidade e confiabilidade. A mudança mais recente no índice foi a adoção da corrente Troll no indicador anunciada em 2017.

A adoção de diferentes grades na produção do índice leva a um problema de qualidade pois cada corrente tem diferentes características físicas que influenciam seu valor. Um mecanismo para ajustar os valores foi o instrumento de ajuste de quantidade de enxofre ou "de-escalator". Com isto a Platts passou a divulgar um índice para ajuste da concentração de enxofre numa corrente específica, colocando uma lógica de mercado nas diferenças de qualidade. Outra característica é de que o produto entregue numa eventual expiração do contrato de BFOE será o grade com menor valor, em geral o Forties, desta forma o que define o valor do índice é o preço da corrente com menor valor. 


\section{2.}

\section{A dimensão financeira}

A dimensão financeira do mercado do Mar do Norte possui diversos instrumentos, sendo os mais importantes aqueles que tem a função de descoberta de preços. A lista de derivativos é extensa, para citar os principais temos Forwards, Contract for Differences (CFDs), Exchange for Physicals (EFPs), Brent futures, Options e Swaps. A negociação destes instrumentos pode ser feita em mercados organizados como a Bolsa Intercontinental Exchange (ICE) ou no mercado de balcão, conhecido como OTC na sigla em inglês (Over the Counter).

Diferentemente de outros mercados, poucos dados estão abertos ao público. A única maneira de acessar os dados das PRAs é via o pagamento de assinaturas, o que faz com que muitos agentes de fora do mercado de energia não participem. Sendo assim, a análise de estatísticas referentes a este mercado será limitada. Mais tempo será despendido na descrição da mecânica do mercado do que na análise dos dados dos participantes em si.

O primeiro instrumento analisado será o Forward Cash BFOE, que se refere, de acordo com Barret (2012), a um contrato em que há a disponibilização pelo vendedor para o comprador de uma carga de petróleo Brent, Forties, Oseberg, Ekofisk ou Troll em um determinado mês no futuro, sem uma data determinada do mês. Este contrato foi primeiramente denominado contrato de 15 dias, pois o vendedor tinha que informar ao comprador com 15 dias úteis de antecedência a janela de 3 dias para a entrega de 500.000 barris com +/-5\% de tolerância operacional do petróleo Brent. Atualmente o período é de 1 mês de antecedência para a nomeação, o volume é de 600.000 barris e a tolerância operacional de $+/-1 \%$ (PLATTS, 2017). Ainda de acordo com Barret (2012) a mecânica de transformação de uma operação "financeira” para "física” segue o seguinte processo:

a) Um contrato Foward Cash BFOE é firmado entre duas partes;

b) $\mathrm{O}$ operador do terminal anuncia o programa de carregamentos antes do começo do mês;

c) Os produtores, que possuem o petróleo, começam a nomear as cargas para os compradores com pelos menos 1 mês de antecedência, ou mantém as cargas para si mesmo. Os compradores que recebem a nomeação da carga podem repassá-la no mercado ou manter para si 
mesmo. Neste momento a carga se torna física (wet), e possui uma janela de 3 dias de carregamento.

d) A carga então, muda de mercado para ser negociada no mercado do Dated Brent, com as cargas podendo mudar de mãos. Entre 10 dias e um mês completo para a data de carregamento são feitas as avaliações de preço (PLATTS, 2017). Exemplo: No dia 1 de março, serão avaliados os preços das cargas com carregamento entre o dia 11 de março a 1 de abril.

Os problemas neste mercado começaram a surgir no início dos anos 2000, quando o declínio da produção do Brent levou ao aumento da possibilidade de manipulações. De fato, de acordo com Barret (2012) entre 2000 e 2002 várias manipulações trouxeram distorções para o preço do mercado. Este foi o principal motivo, como exposto anteriormente, para a introdução do Oseberg e Forties na avaliação dos preços. Além disso para que um número maior de cargas fosse avaliado pela Platts, o período de avaliação do Dated Brent passou a ser de 10 a 21 dias anteriores à data de carregamento. Mais tarde em 2007 o Ekofisk também foi introduzido e o período de avaliação do Dated Brent foi estendido para 10 a 25 dias antes do carregamento, em 2015 o período de avaliação do Dated Brent passou a ser de 10 dias a um mês completo à frente (PLATTS, 2017). Além disso, a partir de janeiro de 2018 o petróleo Troll passou a fazer parte da cesta que pode ser entregue no contrato Cash BFOE. Como agora a entrega pode ser de qualquer um dos cinco grades, não somente o Brent Blend, o preço mais baixo entre os cinco tipos de petróleo passou a ser o relevante para a avaliação da Platts.

Mesmo com a introdução destas mudanças o mercado continua sendo muito restrito, contando com poucos participantes ativos e poucos negócios suportando a formação de preços.

Além do Dated Brent e do Forward Cash BFOE, outro instrumento que tem importância central no mercado de petróleo global é o Contrato Futuro Brent. Este contrato foi lançado na International Petroleum Exchange (IPE) em 1988 após uma série de tentativas frustradas. $\mathrm{O}$ caráter padronizado dos contratos futuros permite que um número muito maior de participantes possam negociar produtores, fundos de pensão, fundos de investimento, investidores técnicos, investidores de índices, entre outros. O contrato especifica a entrega de 1.000 barris do petróleo Brent em um período no futuro. O contrato vence no último dia 
útil do mês e sua liquidação é financeira, sendo que existe uma opção de entrega através de um outro instrumento chamado Exchange for Physicals (EFP). A negociação é toda eletrônica e organizada na Intercontinental Exchange (ICE). O volume de contratos em aberto na bolsa tem uma tendência crescente ao longo dos últimos anos e em 2018 atingiu recordes históricos.

O ajuste do preço no vencimento dos contratos é feito com base nos contratos Forward Cash BFOE explicados anteriormente, ou seja, o valor do contrato futuro no vencimento converge para um índice calculado com base no Forward Cash BFOE, desta forma o mercado futuro depende do mercado forward para ajuste financeiro. Então o processo de descoberta de preço no mercado futuro depende da liquidez do mercado forward, que como exposto anteriormente, não é muito grande e fica concentrada em poucos agentes (FATTOUH, 2011). Esta característica do mercado tem raízes históricas, onde o mercado forward precedeu o mercado futuro. Além disso, segundo Fattouh (2011) nenhum produtor do Mar do Norte suportaria a entrega num contrato futuro com liquidação física.

Embora os contratos não tenham entrega física, os EFPs são os instrumentos que permitem aos agentes trocarem suas posições no mercado futuro por posições físicas. Em resumo, a execução de um EFP significa a conversão de um contrato futuro em um Forward Cash BFOE. Desta forma a importância do EFP é que ele fornece a conexão entre os dois mercados, tendo um papel fundamental na descoberta de preços em momentos de pouca liquidez no mercado forward (FATTOUH, 2011).

O mercado spot do Dated Brent na verdade tem um caráter de "futuro" pois as negociações são feitas para uma carga que será entregue entre 10 dias e 1 mês à frente. Desta forma o negócio é caracterizado como "spot", mas sua efetiva entrega não é feita no momento do fechamento da transação. Para evitar o risco de preço entre a negociação e o efetivo carregamento, pouquíssimos negócios são realizados com base num preço fixo e sim com uma média dos preços do forward em torno dos dias de carregamento.

Neste contexto surgem os contratos por diferenças ou Contracts for Differences, na sigla em inglês CFDs. A importância deste contrato é o de criar uma conexão entre o mercado Forward e o Dated Brent (spot) para diminuir o risco da variação de preços até o efetivo carregamento físico. Os $C F D$ s podem ser negociados na janela da Platts ou fora dela e conta com um número grande de 
participantes. A mecânica de funcionamento é simples e serve para a proteção do risco de base entre o forward e o preço spot na realização. Como exemplo vamos dizer que o preço de venda de uma carga será calculado como a média de 5 dias, em torno da data de carregamento, do Dated Brent. No momento da negociação o comprador poderia vender um Forward para se proteger, porém este hedge não é perfeito uma vez que a diferença entre o Dated Brent e o Forward pode variar no período, para este caso ele deve comprar um CFD também para a semana de carregamento. Os preços dos $C F D$ s são reportados para oito semanas à frente, desta forma, é possível ter um "Forward Dated Brent" para até oito semanas à frente. Fattouh (2011) afirma que este mercado provê um link vital entre o Forward Cash BFOE e o Dated Brent, sendo assim, central no processo de descoberta de preço no mercado do Mar do Norte.

\section{3.}

\section{O processo de descoberta de preço no Mar do Norte}

O processo de descoberta de preço se faz necessário pois nem sempre há negócios suficientes em todas as dimensões físicas que formam o mercado do Mar do Norte. Desta forma as agências de reporte de preços, Platts e Argus principalmente, inferem ou identificam os níveis de preço explorando os diversos instrumentos que formam o mercado do BFOE. O processo começa com a identificação do preço dos contratos Forward BFOE, que representam o valor do petróleo a ser entregue no segundo mês a frente.

$\mathrm{Na}$ sessão anterior foi visto que o contrato que conecta o mercado futuro (ajuste financeiro) ao Forward (entrega física) é o EFP. Portanto, na falta de negociações relevantes de contratos Forward, a observação do preço de um contrato futuro mais o EFP para aquele mesmo mês, produz o Forward. Tão simples quanto a fórmula apresentada por Fattouh (2011):

$$
\text { Forward Brent }(\mathrm{M})=\text { Contrato Futuro }(\mathrm{M})+\mathrm{EFP}(\mathrm{M})
$$

Onde M é o mês da avaliação em questão. Tendo desta forma derivado o preço do Forward, o próximo passo é derivar o preço do Dated Brent, ou o valor spot do petróleo no Mar do Norte. Sua importância é tal que os agentes acreditam que este preço é o reflexo das condições físicas no mercado em determinado dia. 
Tal qual o Forward, o preço do Dated Brent pode ser derivado, na falta de negócios realizados, utilizando um outro instrumento já apresentado aqui, o CFD. Seguindo a formula apresentada por Fattouh (2011) temos:

Forward Dated Brent $=$ CFD + Forward segundo mês

Como os CFDs são precificados para 8 semanas a frente, é possível derivar uma curva de Forward Dated Brent, para cada semana um preço é reportado. Desta forma também é possível derivar uma média de preço para a entrega que ocorrerá entre 10 dias a frente até a mesma data do mês subsequente. Exemplo, se estamos no dia 01 de março, serão avaliados negócios com entrega entre os dias 11 de março e 01 de abril. Este preço é divulgado em valor absoluto em dólares americanos por barril. Como o Dated Brent é a composição de cinco petróleos diferentes, o petróleo que tiver o menor preço será o que irá formar o marcador no fim. O mecanismo de formação de preço do petróleo de menor valor é baseado no seu diferencial. E mais uma vez, em geral o petróleo mais competitivo é o Forties.

\section{4 .}

\section{As conexões entre os mercados físicos e financeiros}

Como vimos na sessão anterior a conexão entre o mercado físico e financeiro no Mar do Norte é feito pelas agências de preço, sendo baseada na metodologia de descoberta de preços. Este trabalho se baseia na hipótese de que o mercado físico e financeiro mantém estreita relação, porém de tempos em tempos há um descolamento entre as expectativas impostas pela dinâmica puramente financeira dos mercados e da economia e a real situação de oferta e demanda em tempo real.

O teste empírico de que os mercados se comportam de maneira ordenada e guardam uma dinâmica conjunta pode ser feita e já foi fruto de vários trabalhos, porém o foco aqui será nas diferenças intertemporais das informações e, por consequência, das decisões dos agentes. 
Segundo Fattouh (2011) o processo de identificação de preços do Mar do Norte é suficientemente robusto para conectar o mercado físico do financeiro. De fato, a metodologia de conexão de preços, como mostrado anteriormente é robusta e demonstra como os mercados no Mar do Norte são interconectados por uma rede complexa de instrumentos. O problema é que esta interconexão traz relações de causalidade diversas. Em alguns momentos o mercado físico forma o mercado futuro e em outros momentos o mercado futuro forma o físico. Esta dinâmica pode ocorrer dado o limitado número de participantes e pode ser evidenciada quando o preço do petróleo negociado no Mar do Norte se descola da dinâmica de preços de grades físicos de outras regiões, negociados baseados em diferenciais.

Como a maioria dos negócios no mercado de petróleo físico é feito com base nos diferenciais para um benchmark, podemos afirmar que os sinais de preço para equilíbrio de oferta e demanda não se dão no preço absoluto e sim, na diferença entre um petróleo físico e o benchmark utilizado. Quando um petróleo físico fica mais caro com relação ao Dated Brent, por exemplo, podemos dizer que há naquele mercado um sinal de que a demanda está superando a oferta, porém, este negócio em específico, não reflete em nada o valor absoluto do petróleo que será precificado, pois seu efetivo preço será baseado no Dated Brent, que neste exemplo simples, pode ter seu preço reduzido no momento da entrega, dado que sua dinâmica é global e baseada nos fatores expostos anteriormente. Portanto uma negociação no mercado físico que surgiu num momento de fortalecimento de demanda sobre a oferta, resultou num preço final menor na entrega.

Este fato fez com que fosse levantada a seguinte pergunta por Horsnell e Mabro (1993): Como mercados que ativamente negociam diferenciais de preço podem formar o preço absoluto de um determinado benchmark? Desta forma Fattouh (2011), numa tradução livre, postula que: O nível de preço do petróleo é formado no mercado futuro. Swaps e forwards formam os diferenciais e, tais diferenciais no fim são utilizados para identificar o preço físico deste benchmark.

O problema do postulado de Fattouh (2011) é que há diversos tipos de petróleo que compreendem diversos agentes e geografias que não são consideradas na formação do preço físico do Mar do Norte. De tempos em tempos podemos ver inclusive que a variação dos diferenciais é tão extrema que subverte a lógica física. 
Como exemplo, podemos notar no gráfico 2, o histórico de diferenciais entre o Petróleo Dalia (API $23^{\circ}$ ), negociado na costa oeste da África, versus o Dated Brent. Pode-se observar que segundo a Argus, durante o ano de 2017 os diferenciais variaram bastante, e mesmo com qualidade inferior ao Forties (API $38,7^{\circ}$ ), principal tipo de petróleo entregue no Mar do Norte, por um período de tempo, o Dalia foi negociado com prêmio para o Dated Brent.

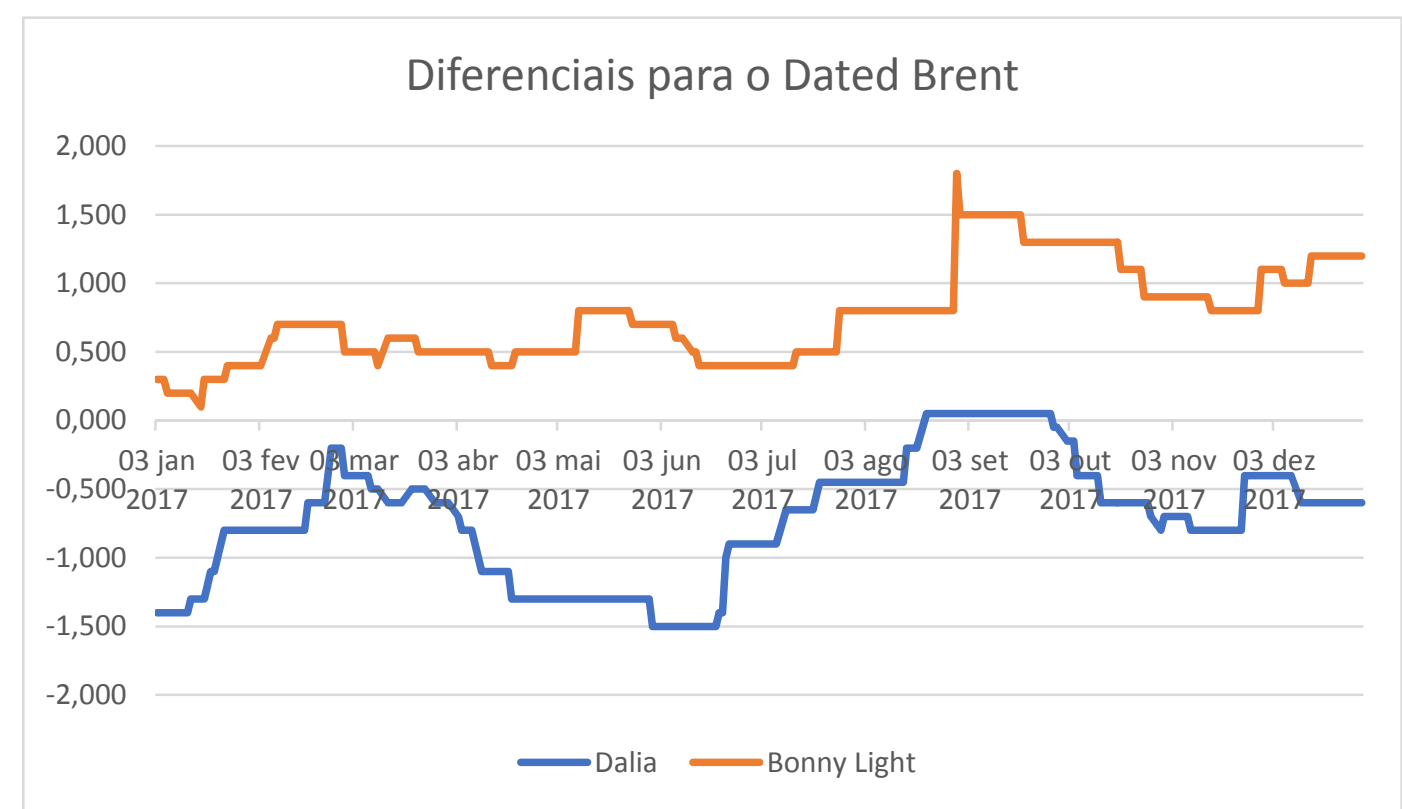

Gráfico 2: Diferenciais de Preço para o Dated Brent

Neste contexto, o mesmo pesquisador, Bassam Fattouh em seu artigo de 2010, afirma que, por mais que haja evidências de que os diversos tipos de petróleo reajam a eventos de preços de forma coordenada, como se houvesse somente um grande mercado, tal dinâmica pode não seguir um processo estacionário no curto prazo. Em adição a afirmação de Fattouh (2010), este trabalho estende tal afirmativa e diz que há uma tendência a descolamentos temporários dos mercados físicos de outras regiões com relação ao Mar do Norte. Estas distorções decorrem do fato de que o mercado do Brent possui uma influência muito grande do mercado financeiro.

Em resumo, os mercados financeiros seguem uma dinâmica coordenada. Em paralelo os mercados físicos seguem também uma dinâmica coordenada entre si, com eventuais descolamentos intertemporais, porém, de tempos em tempos, tais descolamentos se somam e geram grandes distorções. Tais distorções serão explicitadas pelo Índice de Pressão definido na última parte deste trabalho. 


\section{4 \\ Um mercado de diferenciais (Spreads)}

O mercado de petróleo em sua natureza possui uma característica particular. A maior parte das negociações são feitas com base em diferenciais, também comumente conhecidos pelo seu nome em inglês, spreads. Neste capítulo iremos detalhar os dois principais diferenciais e os fatores que influenciam seu valor. $\mathrm{O}$ primeiro deles é a margem de refino, ou seja, quanto uma refinaria recebe após "separar" todos os produtos que são contidos no petróleo cru e na segunda parte será detalhado o spread dos petróleos negociados no mercado spot com relação a um benchmark. Como falamos anteriormente, esta é a principal forma de precificação de vendas no mercado spot de petróleo.

\section{1. Margem de Refino e Crack Spreads}

O petróleo como produto não possui uso específico até que seja refinado. $\mathrm{Na}$ verdade, o petróleo cru, pode ser entendido como uma cesta de produtos com características químicas diferentes que estão misturados. O processo de refino é necessário exatamente para separar estes produtos individualmente para que cada um siga um caminho comercial na cadeia produtiva.

Os hidrocarbonetos contidos no petróleo são diferentes entre si dependendo do número de moléculas de carbono e hidrogênio que possuem e suas formas moleculares, sendo assim, a principal característica, como já citada neste trabalho, a ser observada num petróleo é sua densidade, sendo mais usualmente tratada no mercado como grau API. O grau API possui uma relação inversa com a densidade, sendo que os óleos mais leves possuem graus API mais altos e óleos mais densos ou pesados, possuem graus API mais baixos. 
Os produtos mais leves, como gasolina e diesel, possuem maior valor comercial, portanto, de forma análoga pode-se dizer que tipos de petróleo com maiores graus API, ou seja, mais leves, possuem maior valor comercial que petróleos mais pesados, com graus API inferiores. Tal simplificação vem do fato de que por se tratar de uma cesta, infere-se que um petróleo mais leve possui uma composição maior de produtos mais leves.

A segunda característica mais observada para determinar o valor de um óleo é o seu conteúdo de enxofre. Por se tratar de um contaminante este elemento precisa ser retirado no processo de fabricação dos produtos finais para que estes cumpram especificações estritas criadas por razões ambientais. O processo de retirada deste elemento requer unidades específicas de tratamento e consumo adicional de energia, fazendo com que o custo para refinar um petróleo de alto enxofre seja maior, com isso óleos que possuem alta concentração de enxofre tem valor comercial menor.

Outros elementos químicos também são relevantes para a determinação do valor final que o petróleo terá, porém para este estudo, iremos simplificar a análise a estas duas características principais, API e Enxofre.

Para determinar a margem que uma refinaria receberá após o processamento de um tipo de petróleo, é necessário saber qual a proporção de cada produto será produzida, o valor de cada um deles no mercado e quanto custa este tipo de petróleo para a refinaria. Para o cálculo destes valores, as refinarias utilizam softwares muito complexos de programação linear que otimizam a produção da refinaria e dizem qual o valor máximo que pode ser pago para cada óleo. Para determinar as margens de refino neste estudo utilizou-se o software H/Comet.

O rendimento que cada refinaria terá após o processamento do petróleo irá depender não somente das caraterísticas físicas do óleo, mas também da configuração que tal refinaria possui. Dependendo do número de unidades de conversão e tratamento, o rendimento final pode variar consideravelmente. Além disso, mudanças na forma como os produtos são separados, de acordo com seus pontos de corte, também podem fazer com que o rendimento final se altere de acordo com o preço de mercado dos produtos. 
No gráfico 3 abaixo, podemos notar as diferenças de rendimento para cada tipo de refinaria no período de janeiro de 2016 a dezembro de 2017. Foram utilizados três tipos de refinarias já carregados no software H/Comet e os dados de preços foram são da Platts com seus valores na região da costa do golfo dos EUA.

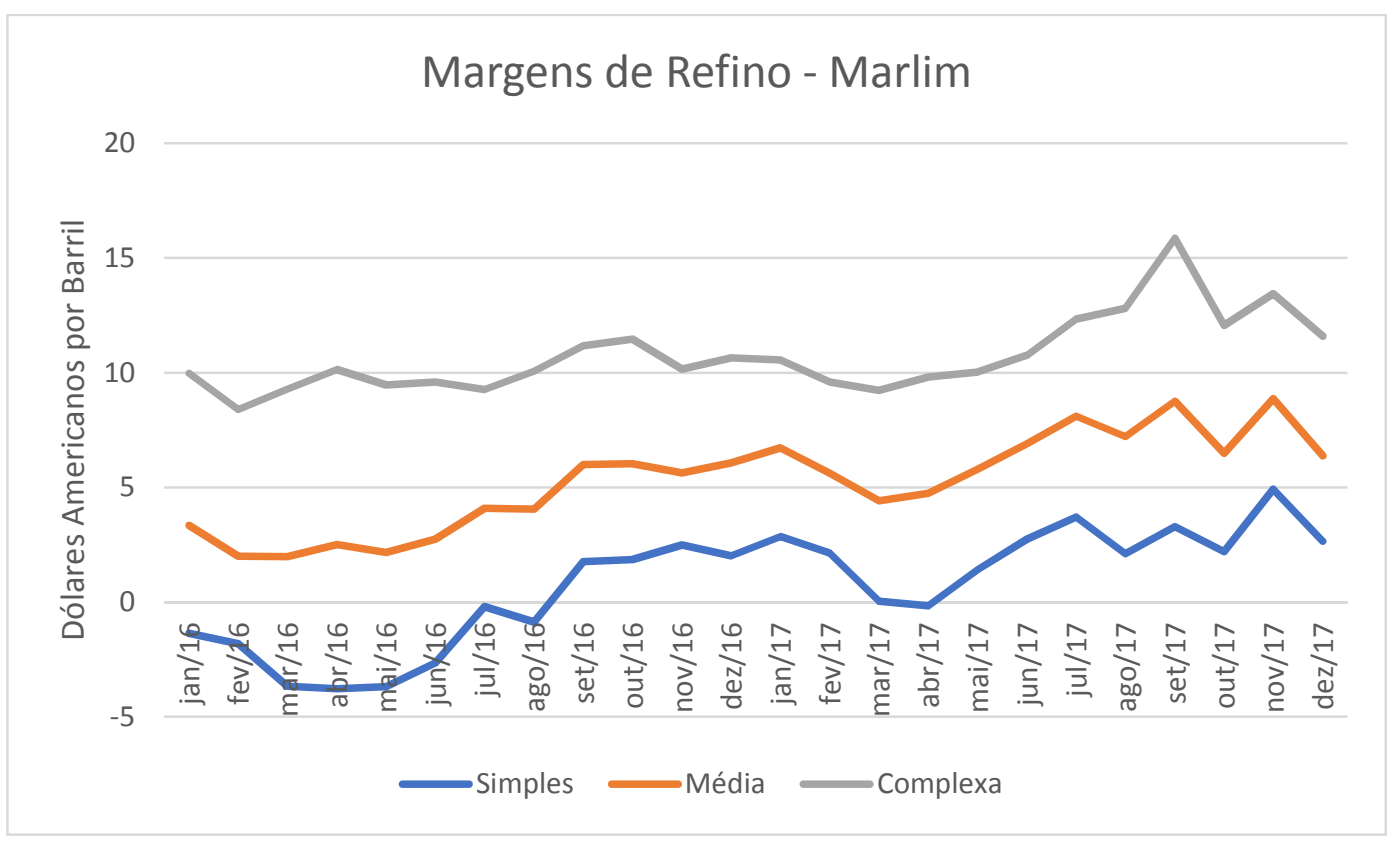

Gráfico 3: Margens de Refino

Para ilustrar como as refinarias possuem alguma flexibilidade na produção dependendo das condições de mercado, podemos notar no gráfico 4 como se comportou a simulação de rendimento numa refinaria complexa para o petróleo Marlim, produzido e comercializado pela Petrobrás, no mesmo período. 


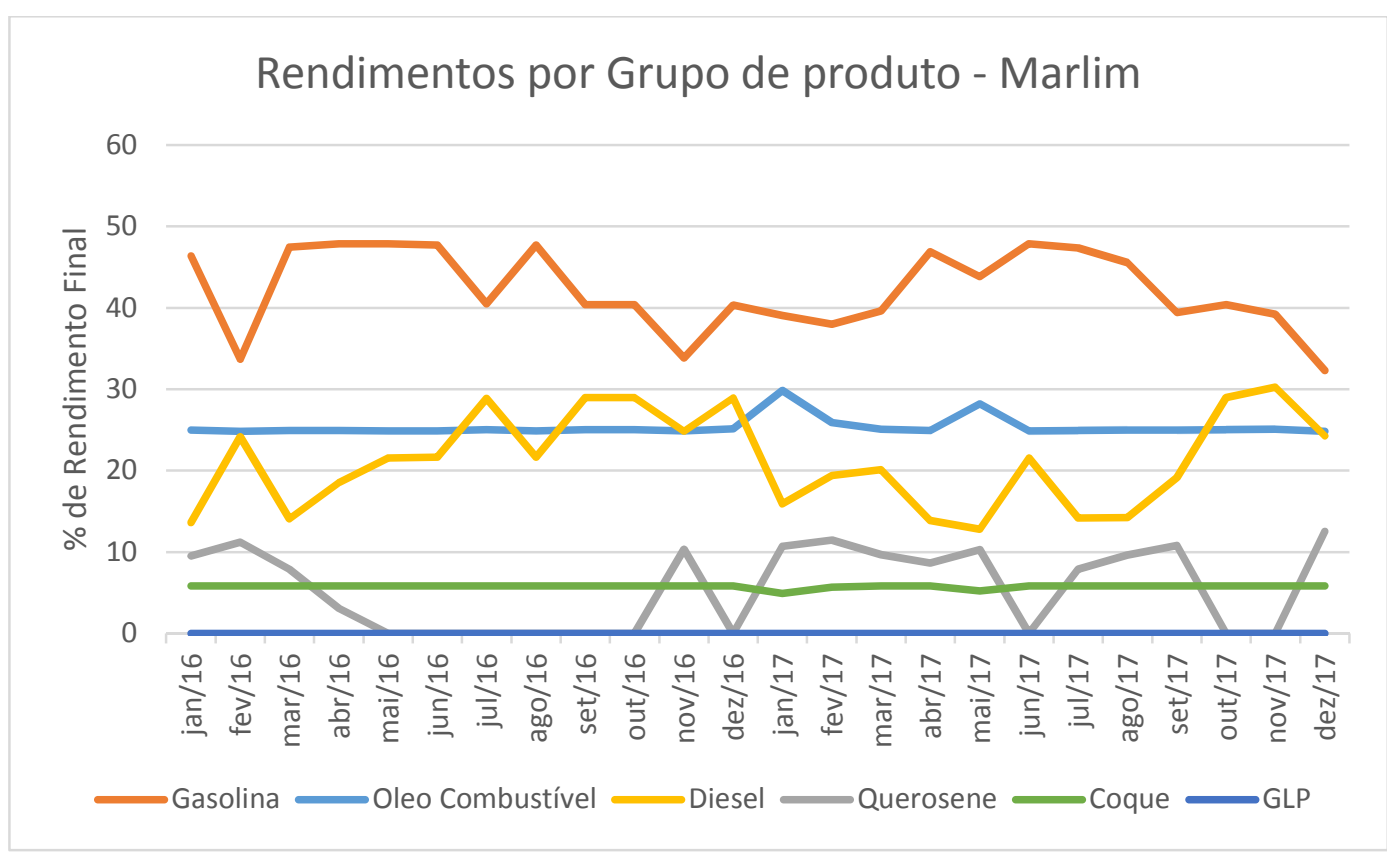

Gráfico 4: Rendimentos por grupo de Produto

Como a análise de modelos de refino complexos demandam muito tempo e conhecimento específico o mercado adotou algumas simplificações para análise das margens de refino de forma dinâmica sendo as mais comuns delas o Crack 3:2:1 para a avaliação de margem do WTI e o Crack 2:1:1 para avaliação da margem do Brent. No caso do petróleo americano, esta simplificação diz que três barris de petróleo do tipo WTI produzem dois barris de gasolina e um barril de diesel de baixo enxofre. No caso do petróleo europeu, dois barris de petróleo produzem um barril de gasolina e um barril de diesel de baixo enxofre. Com isto os agentes de mercado podem estimar a relação de preços em tempo real de acordo com os preços nos mercados futuros de petróleo e derivados.

As margens de refino podem variar por diversos fatores como sazonalidade, capacidade de refino, manutenções, desastres naturais, oferta e demanda de produtos derivados, oferta e demanda de petróleo, entre outros. A explicação de cada efeito na margem demandaria um trabalho inteiro em si, porém como há um objetivo específico no trabalho atual, iremos focar no último ponto que é o da oferta e demanda de petróleo. Os gráficos apresentados acima mostram duas informações importantes sobre a formação das margens de refino. No primeiro gráfico, gráfico 3, pode-se observar que há uma tendência de aumento da margem a partir do início do ano de 2017 que posteriormente se reverteu e retornou a um patamar próximo ao histórico, além disso, observa-se no gráfico 4, que, por mais 
que as refinarias possuam uma certa flexibilidade na escolha dos produtos produzidos não há um variação muito grande na produção final, isto porque a chamada "cesta" de produtos que o Marlim fisicamente possui não pode ser totalmente transformada no processo de refino.

O marlim é um petróleo pesado com grau API de $23^{\circ}$. Aproximadamente $25 \%$ do seu rendimento é de Óleo combustível residual. Isto posto, para que uma refinaria altere a composição final de produtos para atendimento de seu mercado é necessário, não somente que ela altere processos de refino, como também altere sua dieta, ou seja, dependendo dos óleos que forem processados, diferentes produtos serão produzidos.

No ano de 2017 dois eventos podem ser destacados como tendo impacto global no mercado de petróleo o primeiro deles, o acordo de cotas de produção da OPEP e o segundo deles a crise econômica na Venezuela. Ambos eventos tiverem reflexo direto na disponibilidade de petróleo do tipo pesado no mercado.

Primeiramente os cortes de produção da OPEP foram concentrados nos petróleos mais pesados, com menor valor comercial e no caso da Venezuela, a maior parte do seu petróleo produzido é pesado, portanto se há queda na produção do país, há diminuição da oferta de óleos pesados. Desta forma as refinarias passaram a processar menos óleos pesados o que se refletiu, num momento seguinte na queda de produção de produtos residuais que por fim, fez com que seus valores subissem fazendo subir assim as margens de refino para os óleos pesados. No gráfico 5 abaixo podemos notar como o diferencial do óleo combustível de baixo enxofre na costa do golfo se fortaleceu no período. 


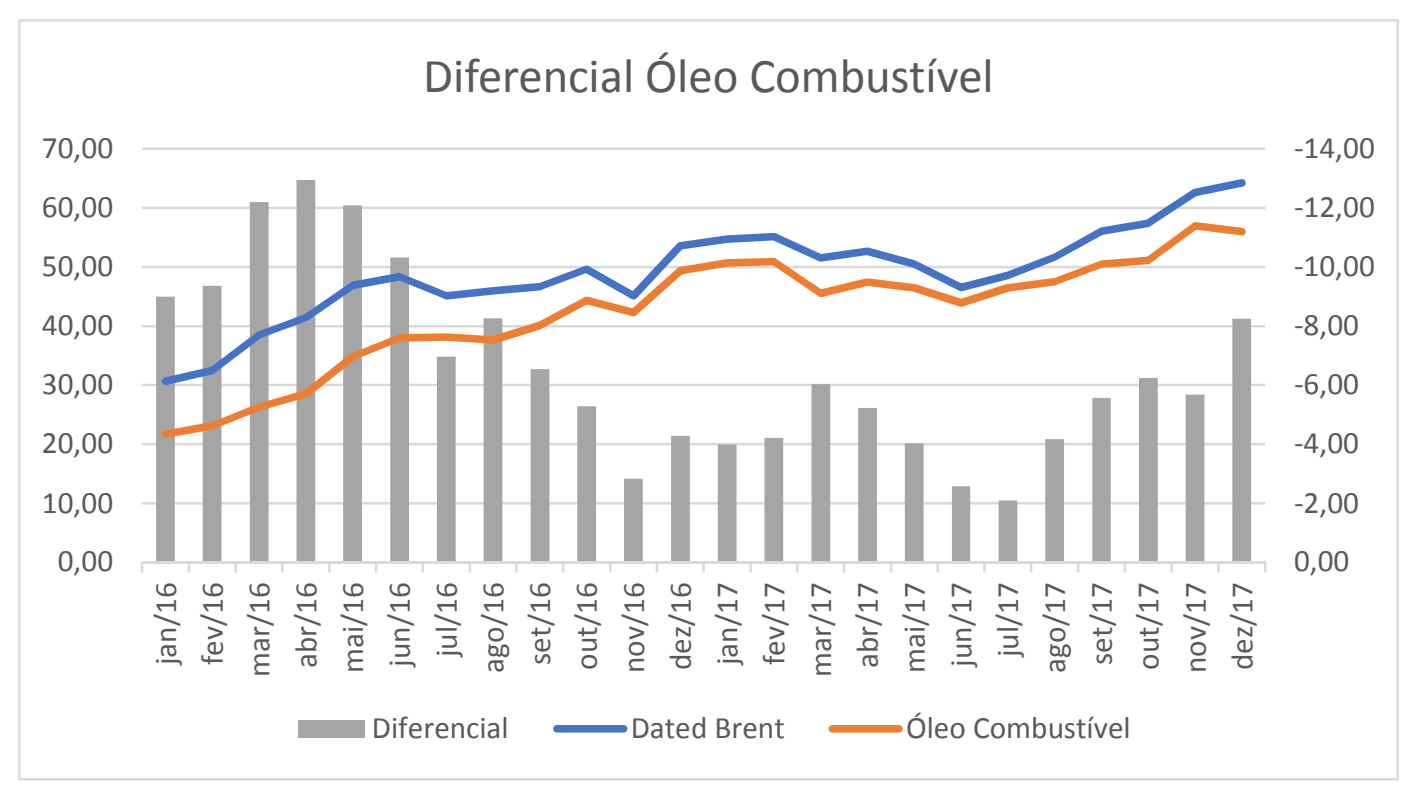

Gráfico 5: Diferencial do Óleo Combustível

Desta forma podemos concluir que uma alteração na oferta de tipos de petróleo pode ter impacto nas margens de refino e que, por processos de arbitragem e ajustes no mercado, tais margens tendem a retornar a um patamar considerado de equilíbrio após alguns períodos.

O pico de margem observado do Marlim mostrado no gráfico 3, porém difere do período em que o preço relativo do óleo combustível ficou mais alto. Este fenômeno ocorre primeiramente pois há um descasamento intertemporal entre os dois mercados, produtos e petróleo e, além disto, as margens de refino como um todo aumentaram de forma estrutural no período seguinte.

Houve, no ano de 2017 um descasamento na velocidade com que o preço do petróleo se movimentou em comparação aos preços dos seus produtos, como visto no gráfico 6 . 


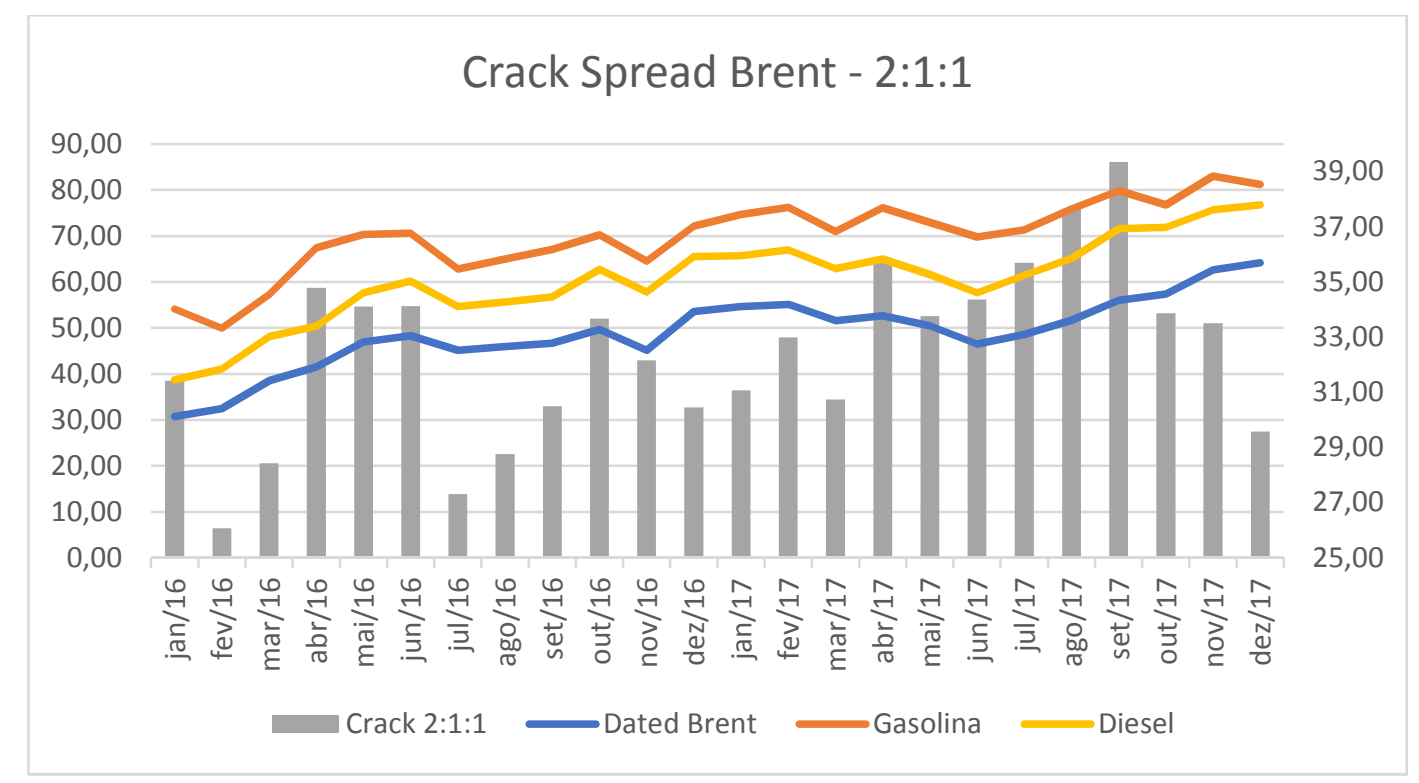

Gráfico 6: Crack Spread

Ainda no gráfico 6, quando observado, por exemplo, o crack spread 2:1:1 no noroeste europeu utilizando os preços de gasolina, diesel de baixo enxofre, e o Dated Brent da Platts, nota-se que há um aumento tendencial nas margens de refino em meados do ano 2017. Tendo seu pico atingido em setembro, quando houve o furacão Harvey. Ambos, petróleo e derivados, ganharam valor no período, porém em velocidades diferentes.

As margens de refino variam muito ao longo do tempo. No gráfico 7 podese observar isto para uma série mais longa de margens de refino do Marlim.

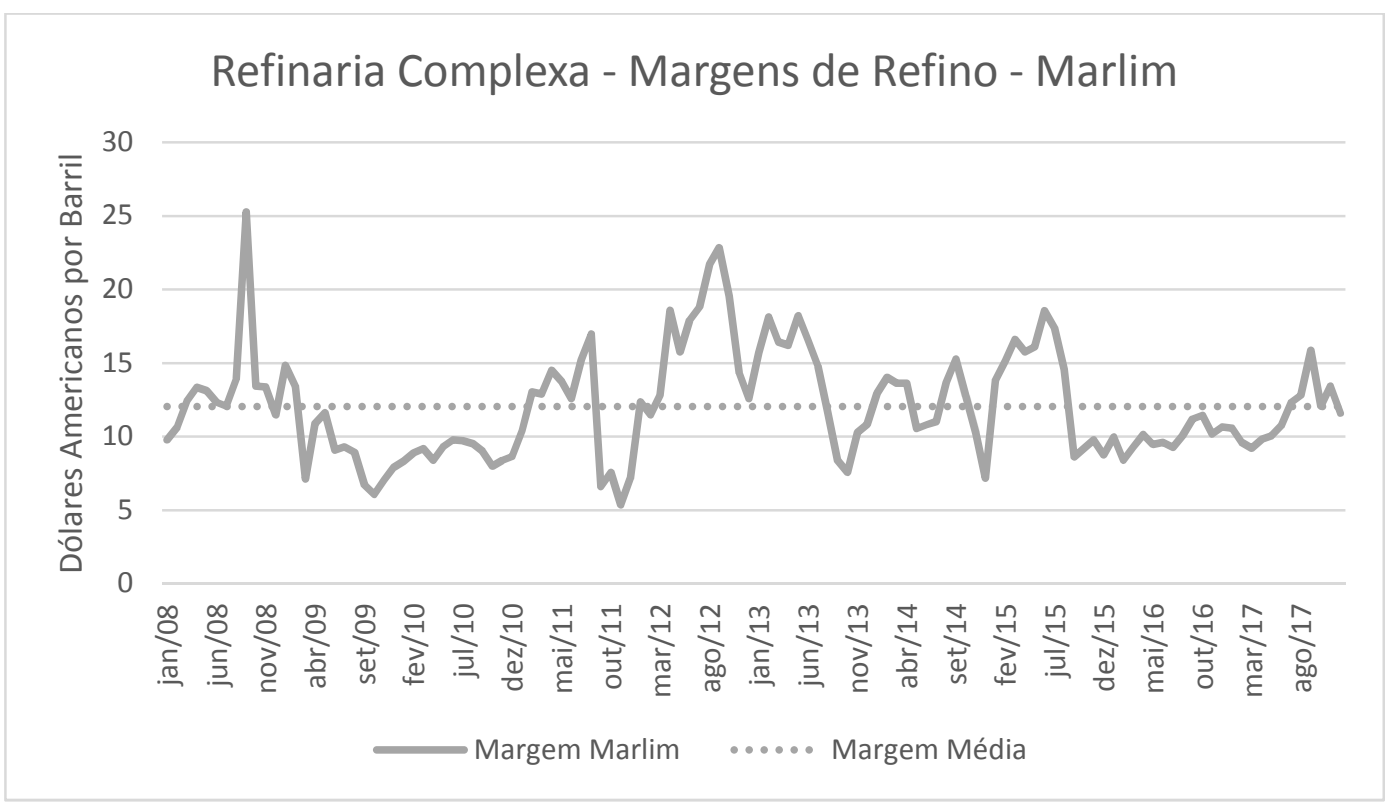

Gráfico 7: Margens Históricas 
Como as margens de refino estão intimamente relacionadas ao mercado físico, de um lado pela demanda dos consumidores e por outro com a oferta de petróleo disponível, acredita-se que alguns insights podem ser construídos sobre os fundamentos do mercado somente observando os valores desta variável com relação à sua média.

\section{2.}

\section{Os diferenciais de preço do petróleo}

Como mencionado anteriormente os diferenciais de preço estão no cerne dos negócios de petróleo. Em geral quando se negocia uma carga no mercado spot não se fala em preço absoluto e sim em diferenciais para algum benchmark. Num leilão de venda por exemplo o vendedor determina qual o benchmark que será utilizado e as ofertas são apresentadas de acordo com descontos ou prêmios com relação a este benchmark.

Os agentes quando conversam sobre preços, em geral referem-se aos diferencias muito mais do que ao preço absoluto e o sentimento de estar caro ou barato sempre é com relação ao histórico de diferenciais de um determinado cru ou, de maneira mais dinâmica, em comparação com os diferenciais de um outro petróleo parecido. Por exemplo, quando se fala que o Vasconia, petróleo colombiano, está "caro" a referência é sempre com relação a um substituto parecido, como o Maya mexicano.

A principal tese que suporta esta afirmação é de que os mercados são conectados globalmente, e tendem a se movimentar de maneira conjunta. Portanto se o diferencial de um petróleo pesado de uma região se fortalece, em geral os óleos parecidos terão um comportamento análogo. Como exemplo podemos notar no gráfico 8 o comportamento dos diferenciais dos seguintes petróleos:

\begin{tabular}{|l|l|r|r|}
\hline Tipo & País & API & Enxofre \\
\hline Dalia & Angola & 23 & $0,5 \%$ \\
\hline Napo & Ecuador & 19 & $2,0 \%$ \\
\hline Marlim & Brasil & 23 & $0,7 \%$ \\
\hline Castilla & Colombia & 18 & $2,2 \%$ \\
\hline Doba & Chad & 25 & $0,1 \%$ \\
\hline
\end{tabular}




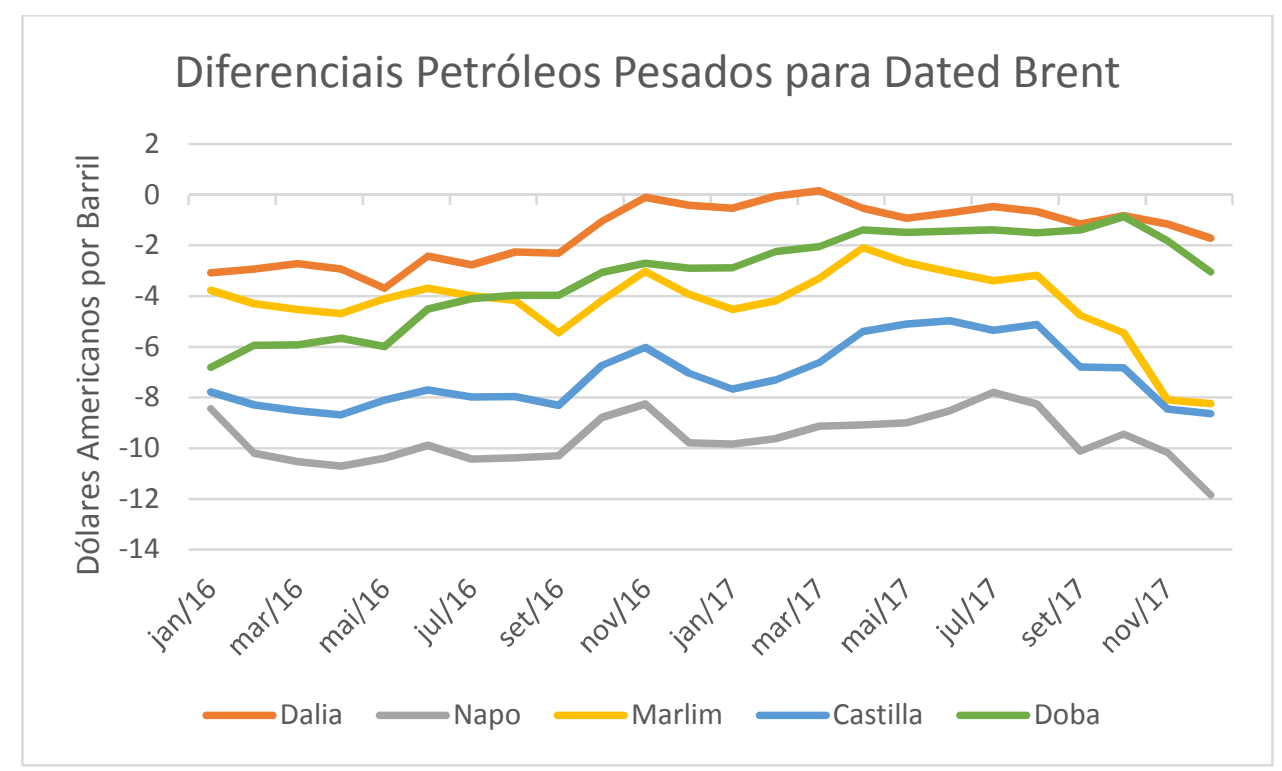

Gráfico 8: Diferenciais de Petróleos Pesados

Visualmente é possível observar no gráfico 8 que, mesmo em regiões diversas, os petróleos com qualidade parecida seguem um comportamento parecido, sendo que os latino americanos parecem ter uma correlação maior entre si.

Isto ocorre, pois, as refinarias que compram e processam determinados tipos de petróleo, podem substituir um tipo por outro, respeitando limites técnicos estabelecidos. Desta forma caso um petróleo pesado esteja ficando muito caro com relação a outro, as refinarias irão optar pelo mais barato e assim sucessivamente, fazendo com os preços relativos se comportem de maneira coordenada.

O mesmo comportamento não pode ser observado entre petróleos de tipos muito distintos, pois como as refinarias possuem diversos objetivos de produção e unidades desenhadas para determinada dieta, dificilmente podem substituir petróleos que possuem características muito distintas. Ou seja, se o conjunto de óleos leves, que têm seus preços movimentados de forma conjunta, começa a ficar barato, com relação ao conjunto de óleos pesados, as refinarias não podem passar a processar uma dieta mais leve, há restrições técnicas que as impedem de fazê-lo. Portanto, óleos com características muito distintas podem ter diferenciais com comportamentos também distintos. 
Na região oeste da África há muitos óleos leves e com baixo enxofre quando comparamos tipos distintos, gráfico 9, de petróleo da mesma região vemos que os diferenciais durante o período de 2016 e 2017 tiveram comportamentos opostos.

\begin{tabular}{|l|l|r|r|}
\hline Tipo & País & API & Enxofre \\
\hline Bonny Light & Nigeria & 33 & $0,2 \%$ \\
\hline Doba & Chad & 25 & $0,1 \%$ \\
\hline
\end{tabular}

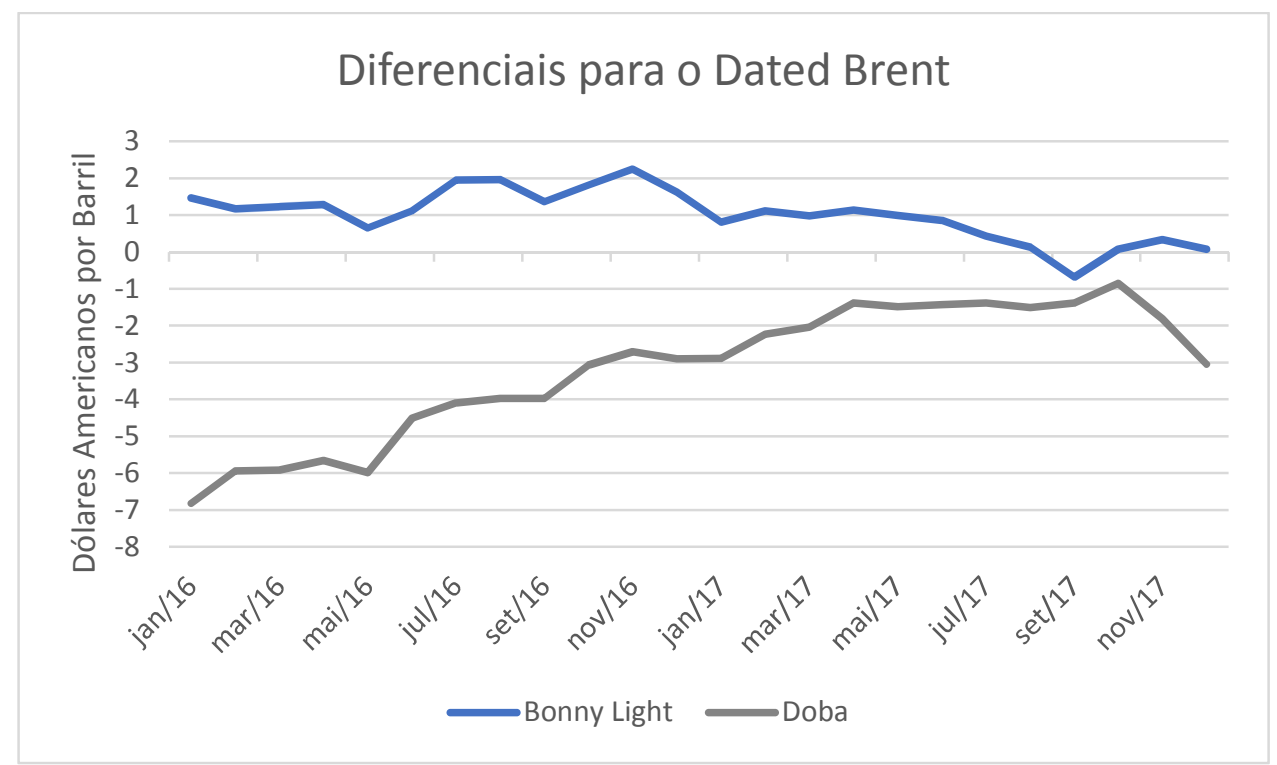

Gráfico 9: Diferencial de Petróleo leve e pesado

No exemplo, o petróleo Nigeriano Bonny Light, se aproxima em qualidade dos óleos que compõem a cesta do Cash BFOE, desta maneira, os diferenciais para o Dated Brent tendem a ficar próximos a zero, pois os mercados podem se arbitrar, ou seja, caso os óleos do Mar do Norte comecem a ficar muito caros com relação ao oeste da África, mais compradores vão seguir para este mercado aumentando assim seu preço e, em movimentos sucessivos, aproximando o valor dos petróleos.

Desta forma, podemos ver que os petróleos que possuem características físicas muito diferentes dos benchmarks têm uma tendência a um descolamento maior nos diferenciais, tanto para cima quando para baixo. Historicamente observou-se que existe uma relação entre a os diferenciais dos petróleos pesados e momentos de restrição no suprimento, ou seja, quando o suprimento global de petróleo está sob pressão, os diferenciais dos óleos pesados tendem a ficar mais 
fortes e em momentos de abundância de suprimento os diferenciais dos petróleos pesados tendem a ficar mais fracos.

Podemos observar este padrão no gráfico 10 abaixo que relaciona os estoques comerciais de petróleo dos estados unidos com o desconto do petróleo pesado colombiano Castilla com API $18^{\circ}$ em relação ao ICE Brent.

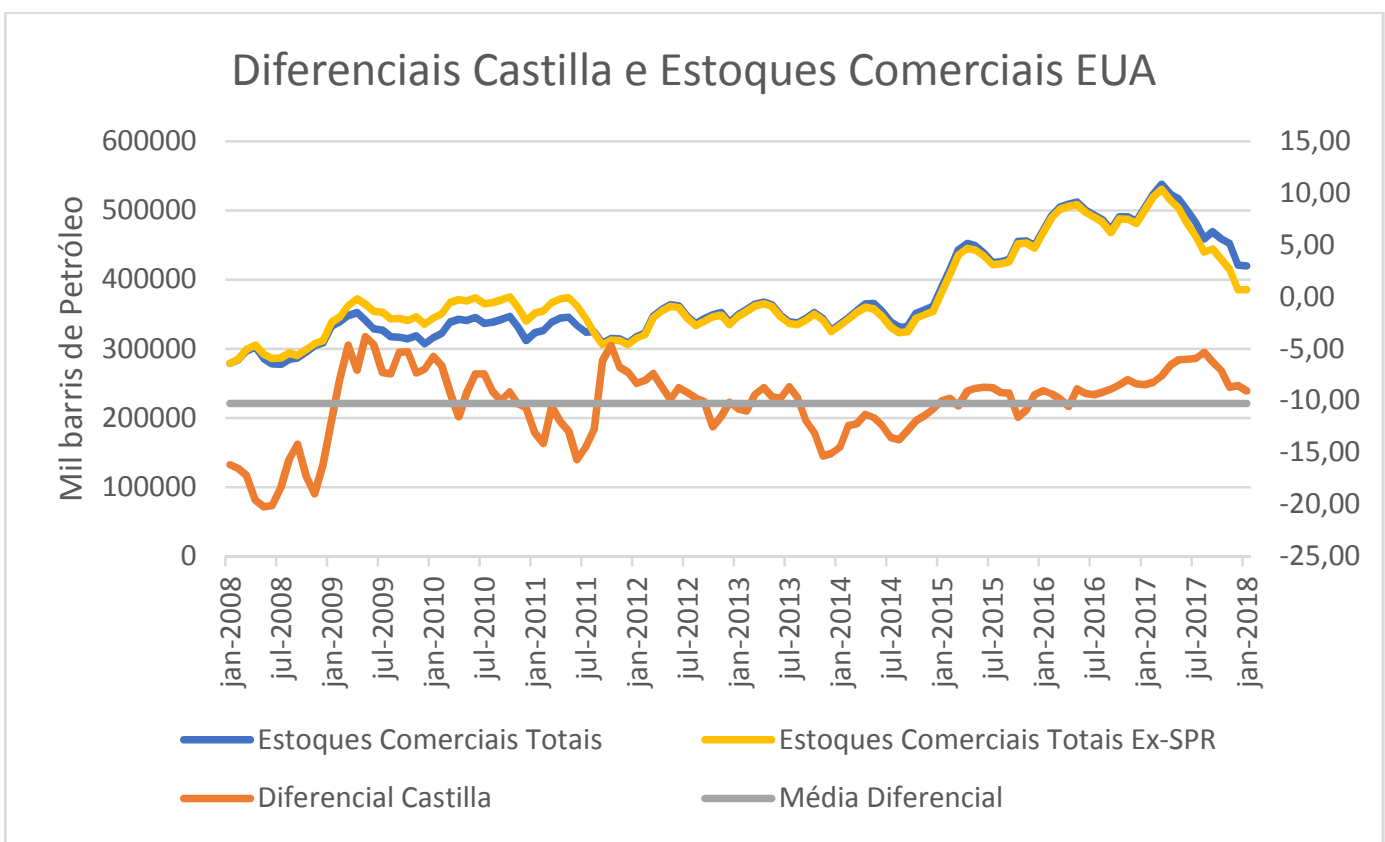

Gráfico 10: Estoques Comerciais EUA e Diferencial de um petróleo pesado

Nota-se que em períodos onde o diferencial está acima da média há uma tendência ao consumo dos estoques comerciais, mostrando que um período de restrição de suprimento faz com que os diferenciais dos óleos físicos pesados se fortaleçam. Este movimento ficou claro em 2017 quando um aumento muito forte do diferencial do Castilla, aqui representando seus pares pesados, prenunciou uma queda acentuada nos estoques. 


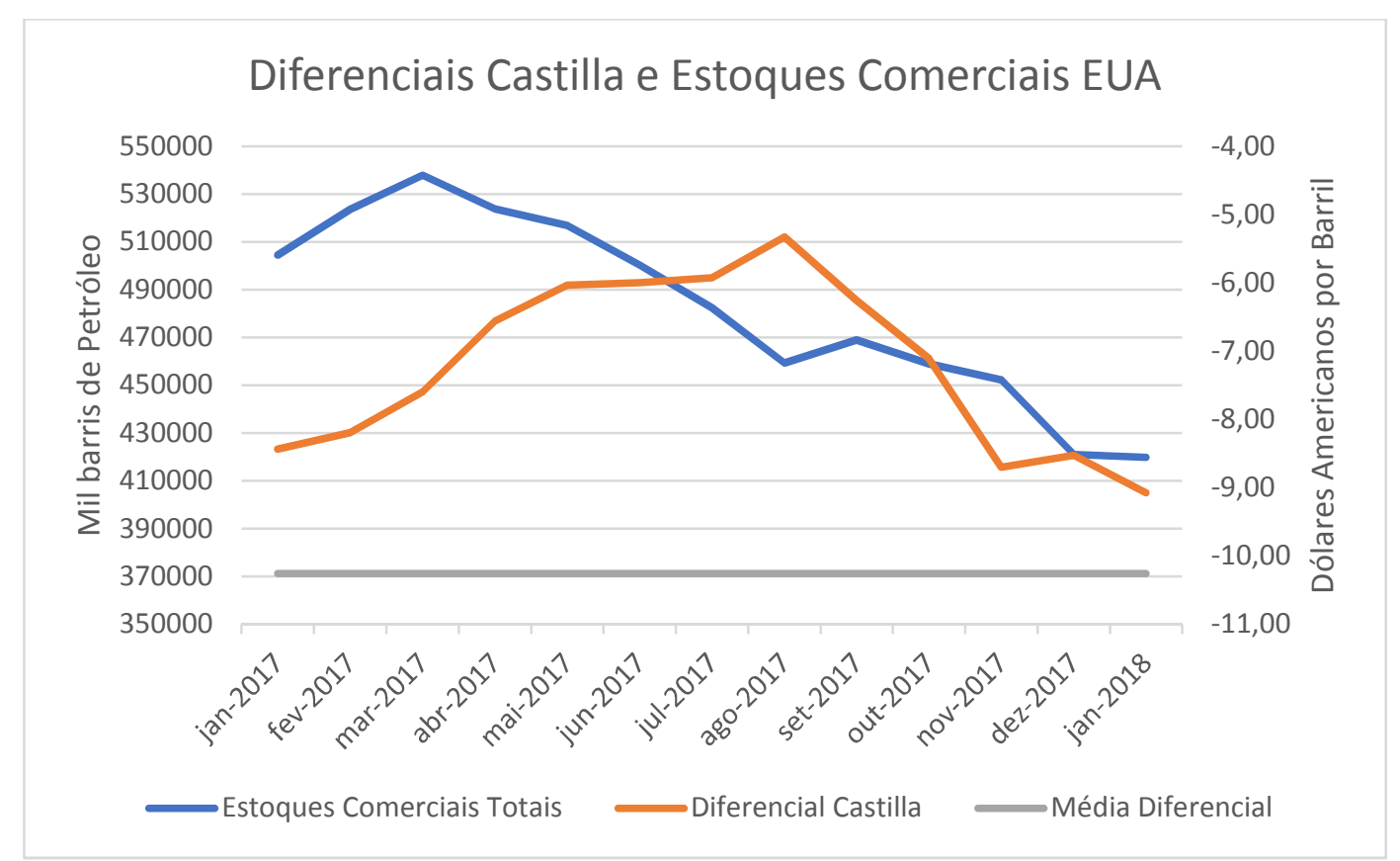

Gráfico 11: Estoques Comerciais EUA e Diferencial de um petróleo pesado

Três suposições suportam o argumento de que os diferenciais dos petróleos pesados se fortalecem em momentos de "seca" do mercado e analogamente, enfraquecem em períodos de abundância de petróleo.

O primeiro é que como os óleos pesados diferem fisicamente dos seus pares utilizados como benchmarks, os diferenciais podem flutuar sem muitas restrições. Ou seja, há muitas barreiras para a substituição dos petróleos leves (benchmarks) por petróleos pesados, portanto é aceitável que movimentos violentos nestes diferenciais ocorram. Podemos ver no gráfico 12 como variou semanalmente nos últimos dez anos o diferencial do Castilla. 


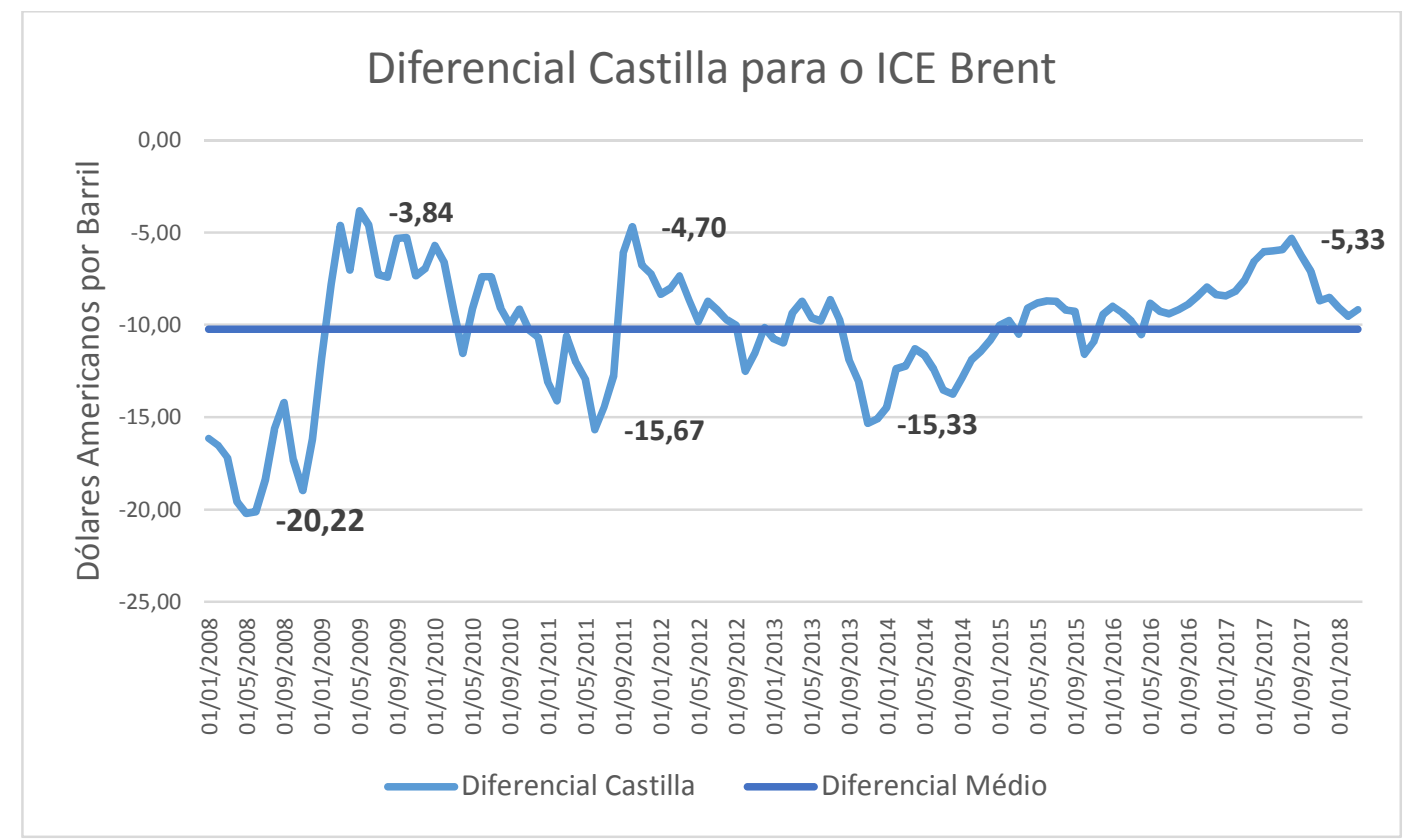

Gráfico 12: Diferencial histórico Castilla

Outra hipótese é que por se tratarem de petróleos difíceis de serem refinados, muitos são tratados como petróleos de "oportunidade", não necessariamente fazendo parte da dieta básica das refinarias. Desta forma, quando há falta de óleos "normais" que podem facilmente ser processados, naturalmente as refinarias começam a migrar para qualidades inferiores mesmo que com margens menores de refino, fortalecendo assim os diferenciais dos petróleos pesados.

A terceira hipótese é a de descolamento do mercado financeiro do físico. Nos últimos anos, muito se debateu sobre a financeirização do petróleo e de fato há uma grande correlação entre variáveis financeiras e movimentos no mercado de petróleo. Com isso, caso haja um descolamento entre os dois mercados, a transmissão de tal distúrbio para o benchmark físico e, consequentemente para seus pares de qualidade parecida, é mais fácil. Como vimos há diversos canais de interligação entre as dimensões físicas e financeiras de um benchmark. Estes canais, porém, não existem entre a dimensão física dos benchmarks e outros petróleos, tal dinâmica de transmissão deve ocorrer via arbitragens entre os mercados, mas se há barreiras técnicas de arbitragem, tais distúrbios do mercado financeiro, se revelam nos mercados físicos. 


\section{5 \\ As distorções do mercado e suas reversões: o índice de pressão}

No capítulo anterior foi mostrado como alterações na oferta e demanda de petróleo tem impacto nas margens e diferenciais dos diversos petróleos. Neste capítulo tais efeitos serão combinados com a intenção de criar um indicador que, por ser baseado nas forças de mercado correntes, antecipe eventuais informações de fundamentos posteriormente divulgadas ao mercado e sirva como informante em tempo real de que distorções entre o mercado físico e financeiro estão ocorrendo. Este efeito reforça a hipótese de Kilian (2009) de que choques transitórios de oferta e demanda de petróleo não tem efeito sobre os preços de petróleo, mas possuem impacto direto nos diferenciais e margens.

Nesta direção, será apresentado o Índice de Pressão que diz que em determinados momentos o mercado financeiro "constrói” o valor do petróleo baseado em informações passadas de fundamentos bem como suas expectativas, variáveis financeiras e dados econômicas. Não levando em conta no curto prazo, informações de fundamentos correntes de mercado que deveriam de fato mover o preço do petróleo. Tal efeito tende a ser revertido em períodos seguintes quando os dados dos fundamentos são divulgados e passam a ser levados em consideração pelos agentes que atuam no mercado financeiro.

\section{1.}

\section{A combinação dos diferenciais}

A principal hipótese que suporta a análise é de que choques de demanda e oferta no mercado de petróleo tem efeito nos seus diferenciais, mas que se estas posições se mantiverem por um período longo serão traduzidas nos dados de fundamentos divulgados posteriormente para então serem transmitidas para os preços futuros do petróleo, retornando assim com os diferenciais para os níveis de equilíbrio. 
Esquematicamente iremos descrever os seguintes cenários para ilustração desta afirmativa. 1) quando o preço do benchmark financeiro ICE Brent está alto com relação aos mercados físicos, há uma tendência de queda dos preços futuros para retorno ao equilíbrio; 2) quando o preço do benchmark financeiro ICE Brent está baixo com relação aos mercados físicos, há uma tendência de aumento dos preços futuros para retorno ao equilíbrio.

Utilizando dados semanais de preços, foram isolados dois períodos de tempo em que os efeitos aconteceram. Será utilizado o petróleo colombiano Castilla por ser considerado um petróleo amplamente negociado em várias regiões do mundo e com muitos vendedores e compradores. Além disso, este óleo é pesado, sendo assim, como já exposto anteriormente, ele sofre um impacto maior das distorções. Por ter spreads grandes, outros efeitos menores, como os preços de frete, podem ser ignorados, pois estes se apequenam frente à amplitude dos diferenciais. Para esta análise, o valor total dos produtos derivados do Castilla será considerado no valor fixo de $\$ 100$ por barril para que o efeito dos diferenciais fique mais claro.

A primeira situação pode ser ilustrada, no gráfico 13 , no período de agosto de 2013 a fevereiro de 2014.

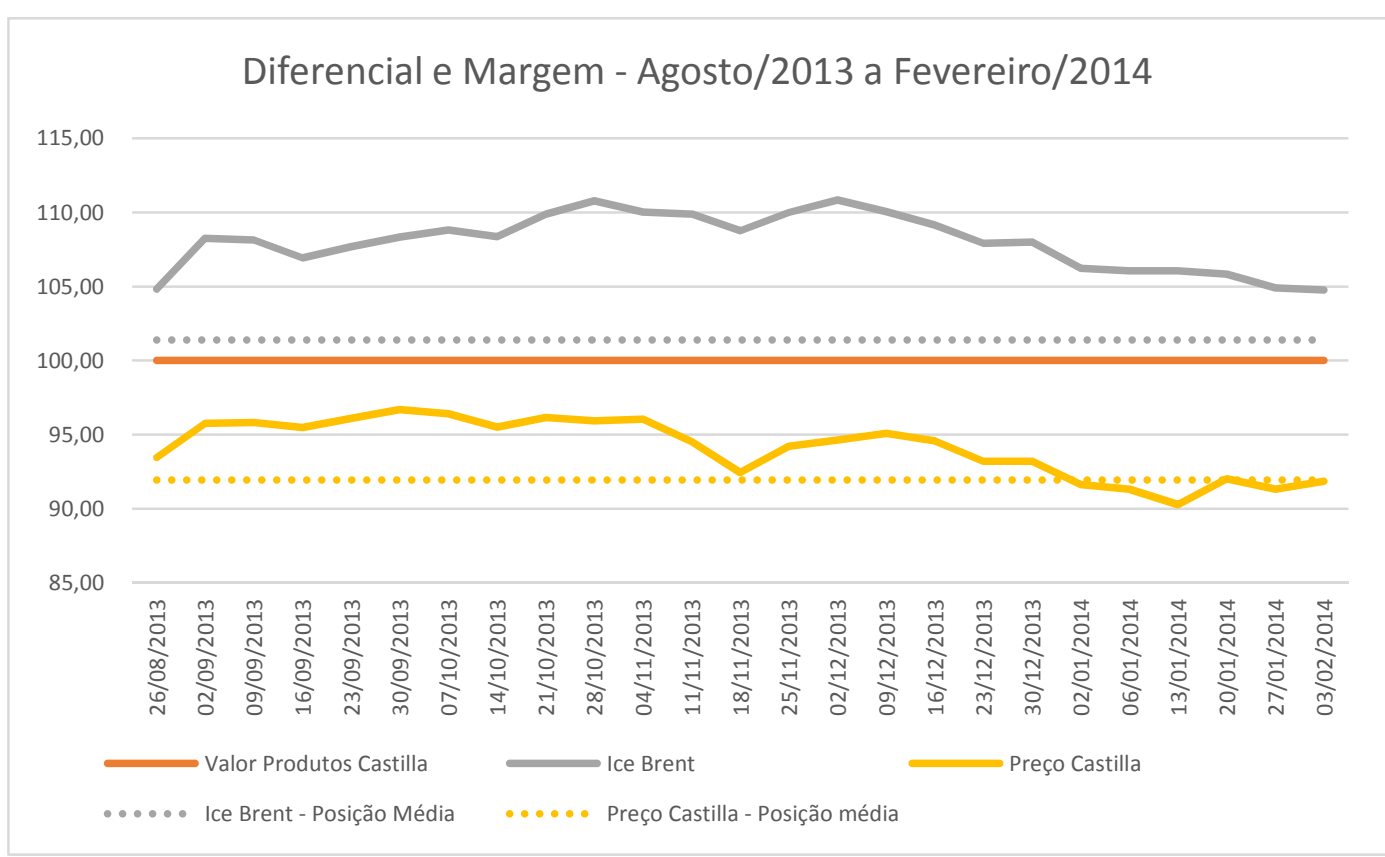

Gráfico 13: Preço do Ice Brent sobrevalorizado 
Neste exemplo pode-se notar que o preço do ICE Brent, representado pela linha cinza, está acima da sua linha considerada de equilíbrio. Neste exemplo o equilíbrio está representado pela média aritmética do diferencial semanal para o período de janeiro de 2009 a março de 2018. Neste caso há uma tendência à queda do preço do futuro pois este se encontra num patamar artificialmente alto. Quando observado o gráfico 14 de volume total de contratos em aberto na bolsa ICE, notase que este período marcou o nível recorde até então observado na série histórica, dando assim alguma pista de que o mercado financeiro estava muito ativo e possivelmente se descolando do mercado físico.

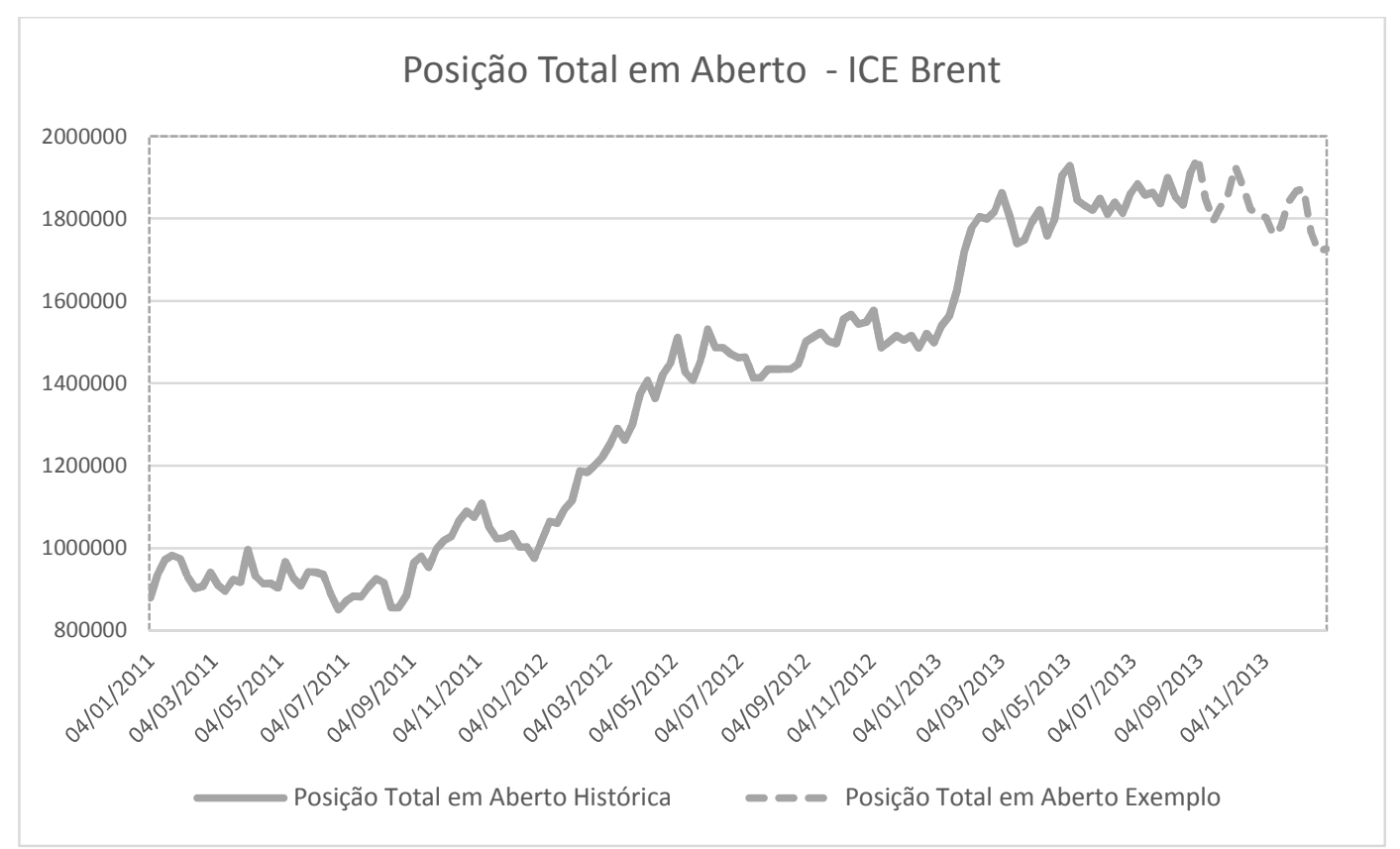

Gráfico 14: Volume total de posições em aberto ICE Brent

A próxima situação pode ser ilustrada no gráfico 15 para o período de abril de 2017 a agosto de 2017. 


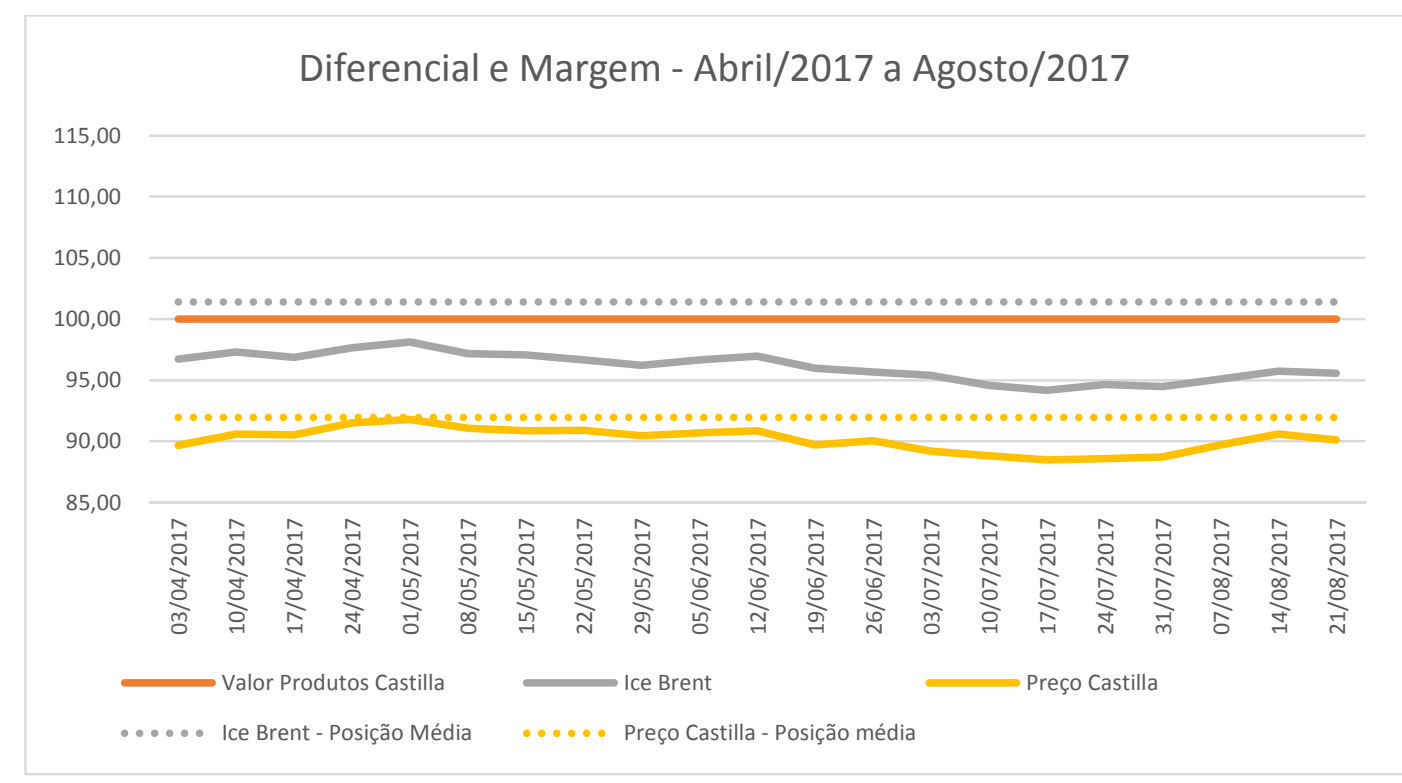

Gráfico 15: Preço do Ice Brent subvalorizado

Neste caso, pode se dizer que há uma tendência ao aumento do preço do ICE Brent neste período, pois seu valor encontra-se abaixo do valor de equilíbrio. Equilíbrio este representado pela mesma média do exemplo anterior. Com relação a posição total em aberto de contratos futuros na bolsa ICE, pode-se notar no gráfico 16 que o comportamento é o mesmo, atingindo extremos na comparação com a série histórica.

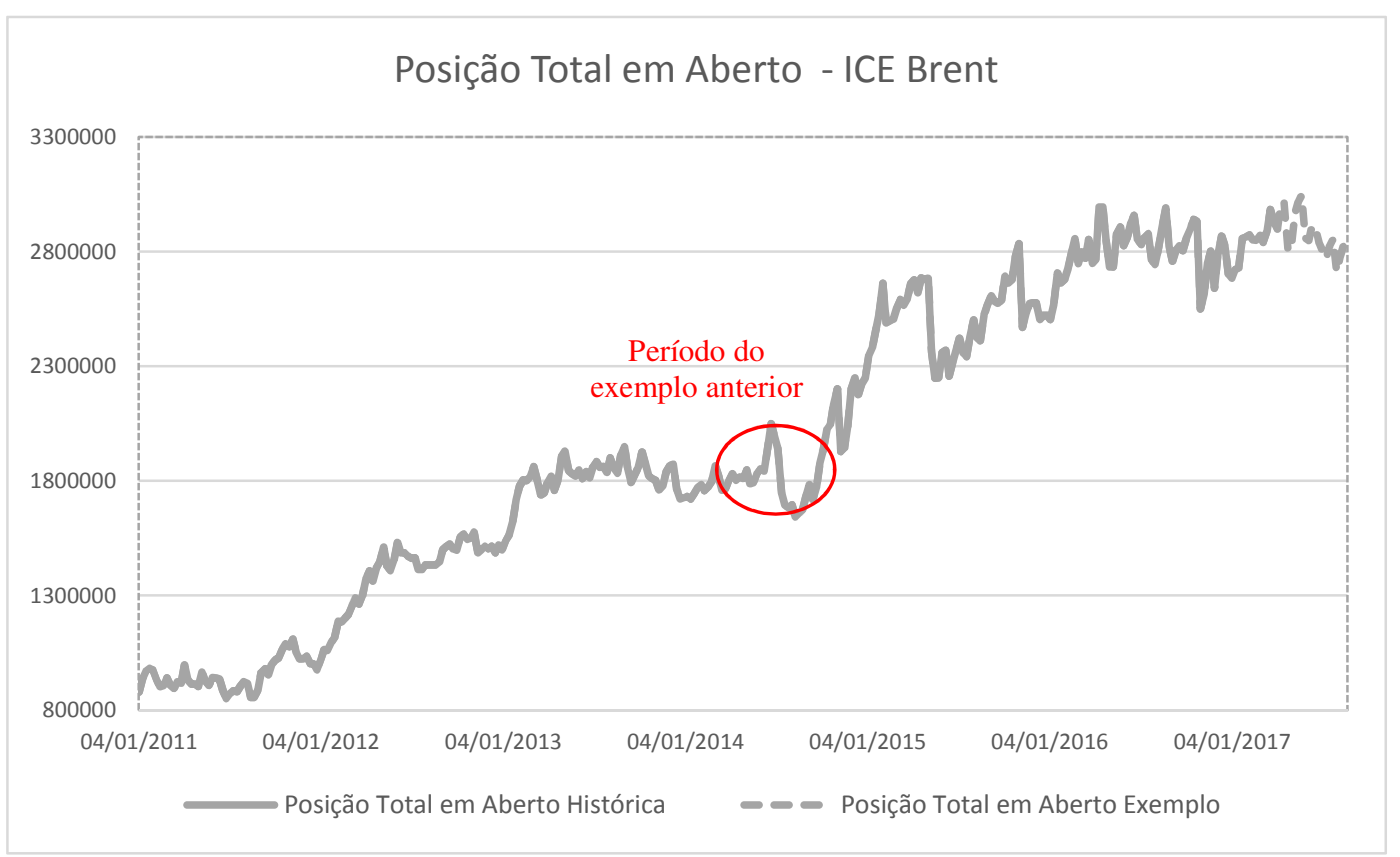

Gráfico 16: Volume total de posições em aberto ICE Brent 


\section{2.}

\section{O índice de pressão}

Para que o efeito apresentado na sessão anterior fique mais evidente podemos unificá-lo num só índice, aqui chamado de Índice de Pressão:

Índice de Pressão = $($ GPW - ICE Brent $)+($ Castilla - ICE Brent $)$

Onde, GPW (gross products worth) é a soma do valor dos produtos derivados de um determinado petróleo, ICE Brent é o valor do primeiro vencimento do contrato futuro de petróleo negociado na bolsa ICE e Castilla é o valor do petróleo spot divulgado por alguma das PRA, no caso aqui apresentado, pela Platts.

Esquematicamente, o índice de pressão pode ser representado conforme os gráficos 17 e 18 abaixo.

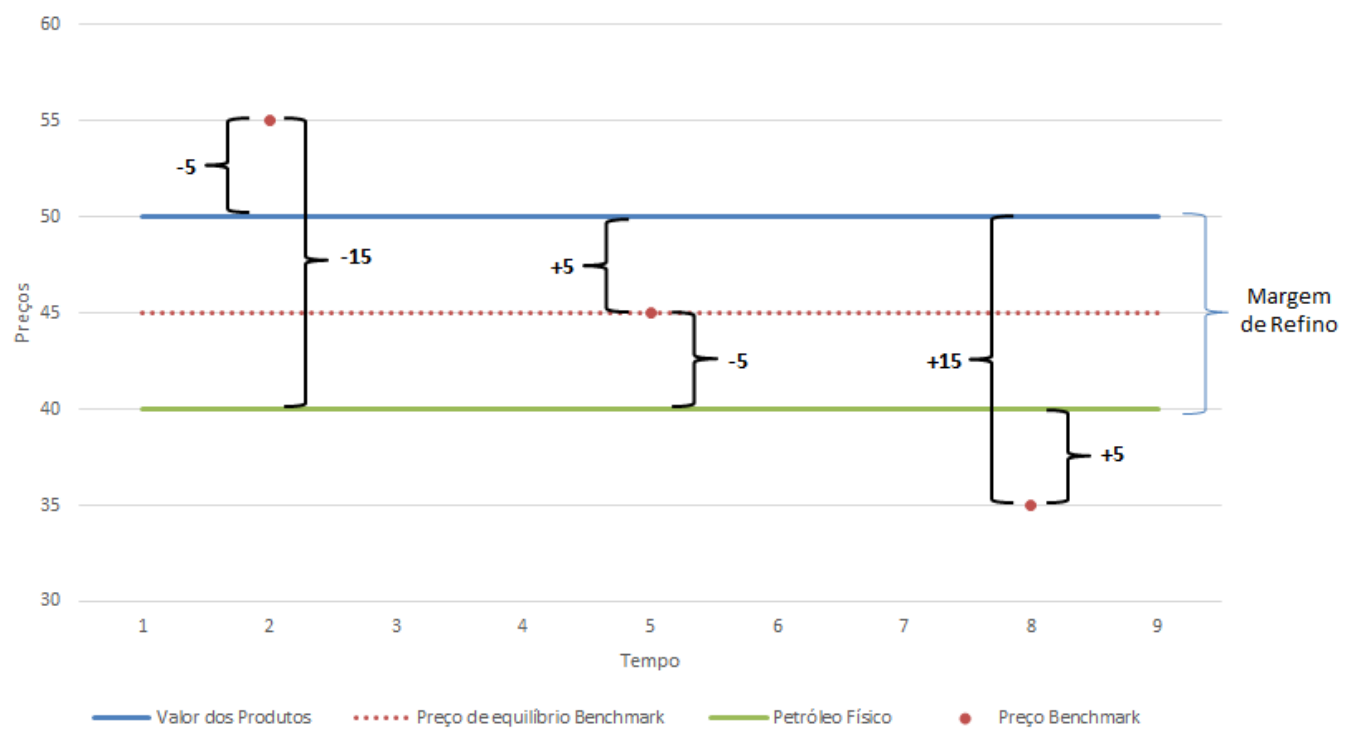

Gráfico 17: Representação esquemática do Índice de Pressão

Podemos notar que no ponto mais à esquerda no gráfico 17 , o preço do ICE Brent, ou do benchmark escolhido possui um valor acima do valor dos produtos de um determinado petróleo, o que representa uma margem negativa. Além disso, neste mesmo ponto, nota-se que o diferencial do petróleo físico com relação ao benchmark está muito negativo, representando que o mercado físico está muito ofertado ou muito "barato". No ponto do centro, está representada a situação de 
equilíbrio, onde os valores dos petróleos físicos de uma região estão em consonância com a situação média do benchmark e com sua dimensão física. No ponto mais à direita do gráfico, temos uma situação análoga, onde o preço do benchmark representado está muito baixo e o referencial físico está caro, nesta situação o preço do benchmark deveria subir para o retorno ao equilíbrio.

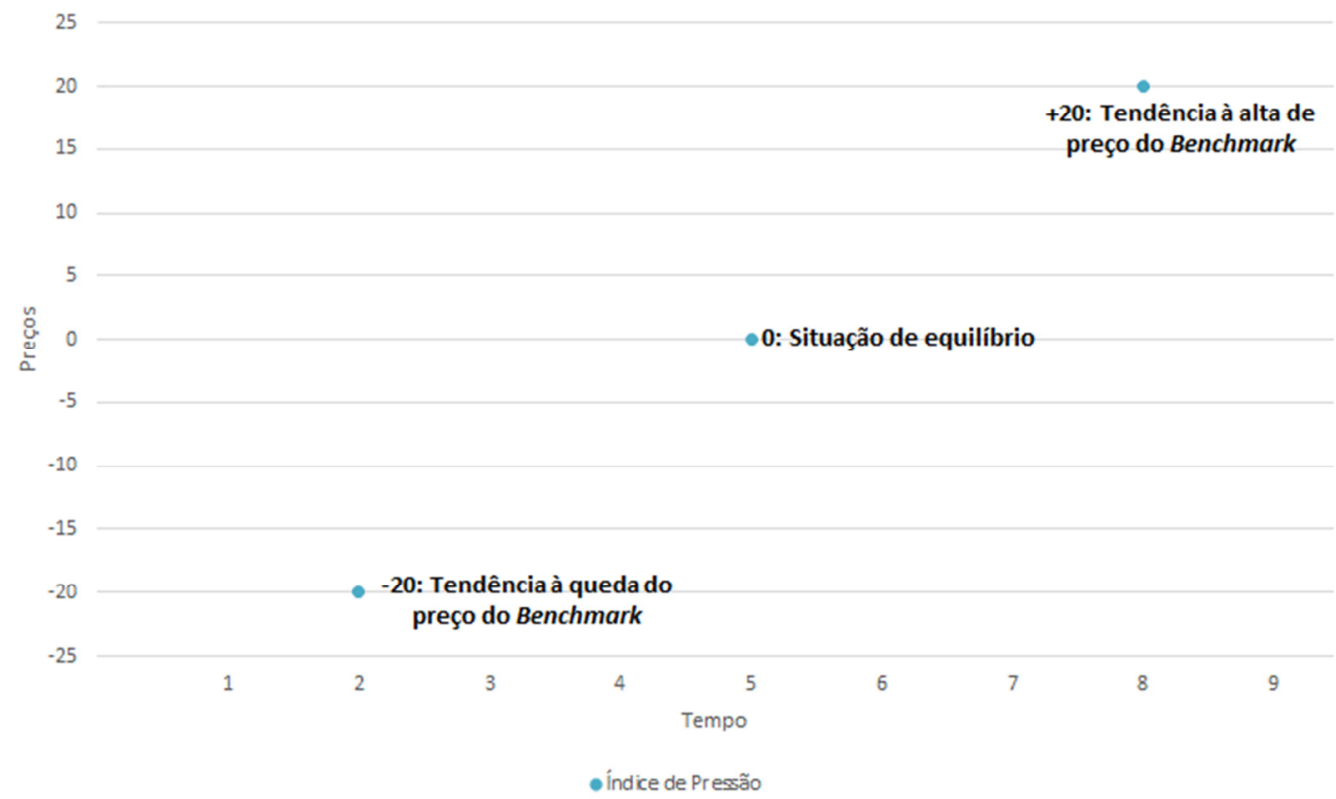

Gráfico 18: Representação esquemática dos valores do Índice de Pressão

Para os dois períodos apresentados no exemplo do capítulo anterior teríamos os seguintes valores nos gráficos 19 e 20.

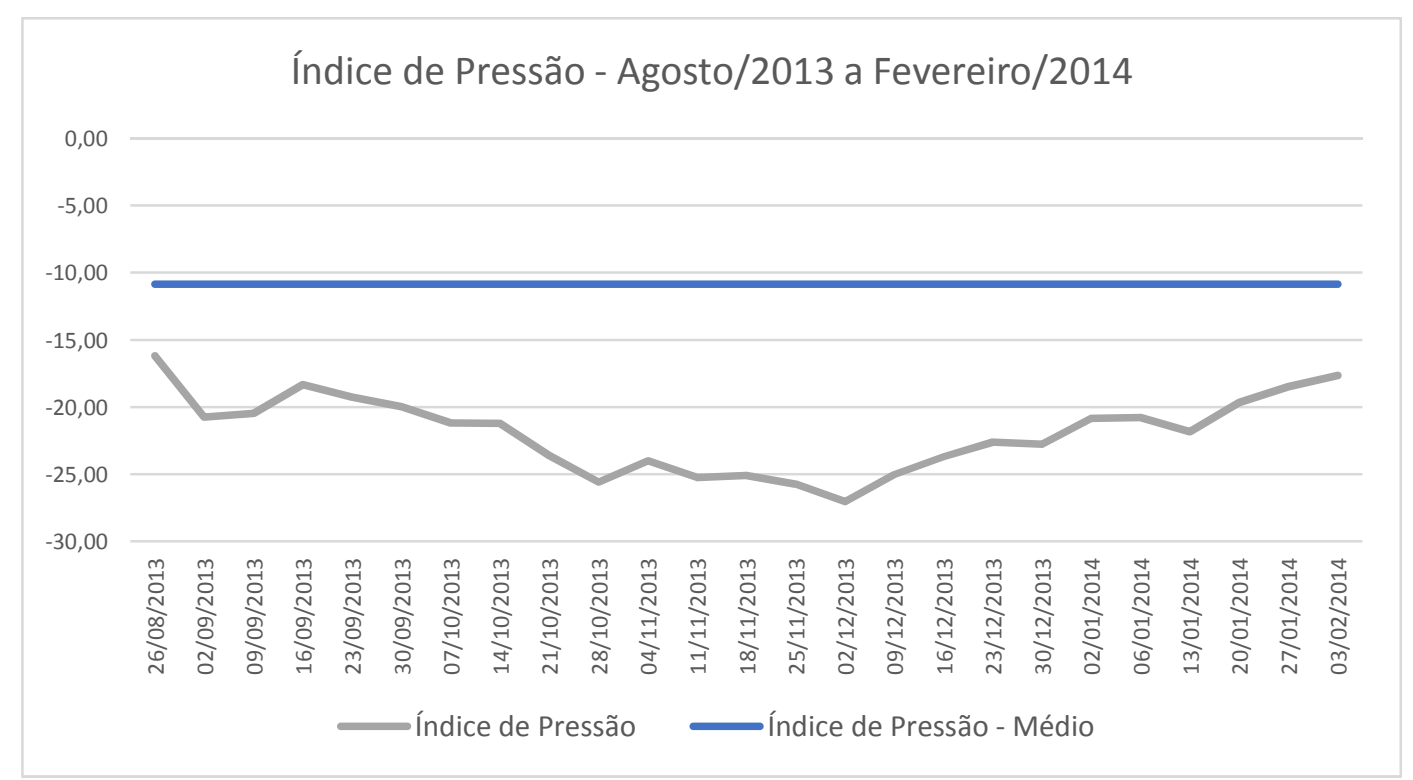

Gráfico 19: índice de Pressão abaixo da Média 


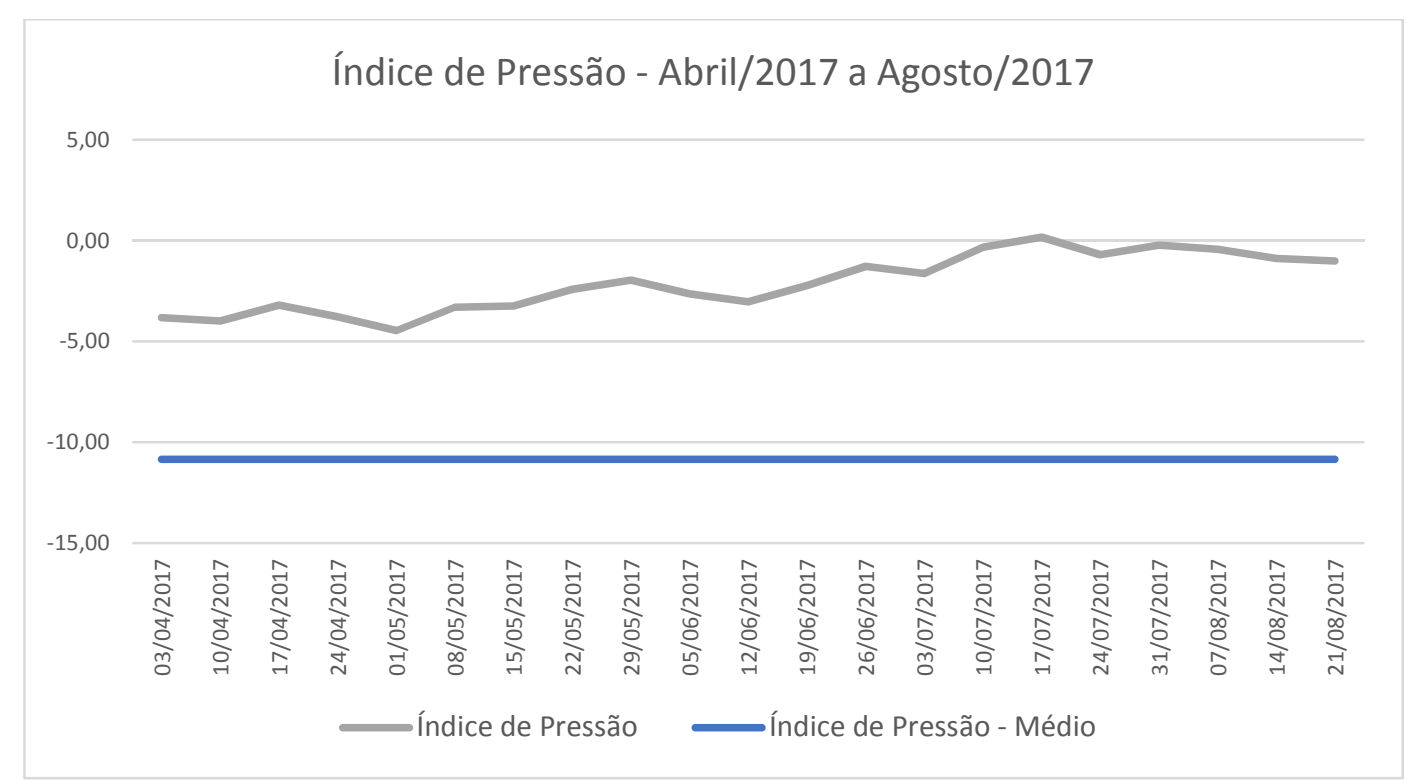

Gráfico 20: índice de Pressão acima da média

A posição abaixo da média do período de janeiro de 2009 a março de 2018 mostrada no gráfico 19, representa que o preço do contrato futuro está sobrevalorizado e, portanto, está sendo pressionado pelo mercado físico a cair.

A posição acima da média mostrada no gráfico 20 representa que o contrato futuro está subvalorizado e recebe uma pressão do mercado físico para subir.

Visualizando o comportamento histórico do índice desde 2008 no gráfico 21, vemos que há uma tendência de retorno à média e, na maior parte das vezes a reversão à média do índice se deu com a movimentação do preço do petróleo cotado no mercado futuro. 


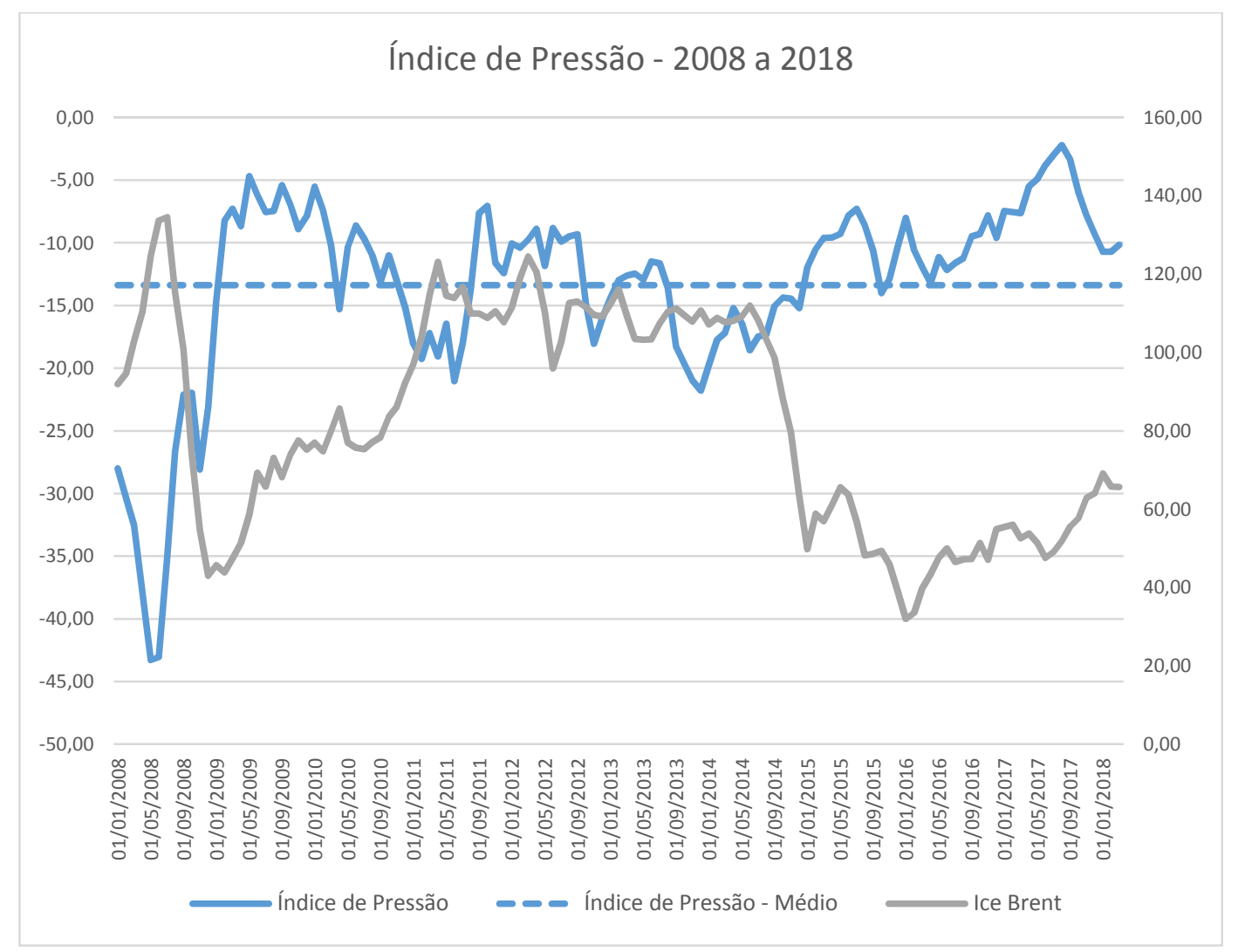

Gráfico 21: Comportamento Histórico do índice de Pressão

Aplicando-se o teste aumentado de Dickey-Fuller com 12 defasagens, por se tratarem de dados mensais (Wooldrige, 2016), para os valores do Índice de Pressão de janeiro de 2008 a março de 2018, obteve-se o seguinte resultado utilizando-se o software EViews:

\begin{tabular}{lccc}
\hline & & Estatística- $t$ & P-valor \\
\hline \hline Teste aumentado de Dickey-Fuller & & $-3,56$ & 0,0081 \\
\hline Valores Críticos (Wooldridge, 2016) & $1 \%$ & $-3,43$ & \\
& $2,5 \%$ & $-3,12$ & \\
& $5 \%$ & $-2,86$ & \\
& $10 \%$ & $-2,57$ & \\
\hline
\end{tabular}

Comparando o valor obtido da estatística- $t$ aos valores críticos do teste ADF (WOOLDRIDGE, 2016) rejeita-se a 1\% a hipótese nula de que a série possui uma raiz unitária. Com isto podemos amparar a afirmação de que há reversão à média na série temporal no período estudado. 
Fazendo uma análise do gráfico 21, podemos ver que, a principal exceção da série ocorreu no ano de 2011, em que o índice mostrava que o aumento de preço no mercado futuro não tinha relação com o mercado físico, mas mesmo assim o preço futuro resistiu e se fixou num patamar acima de $\$ 100$ por barril revertendo assim o índice sem uma efetiva queda no preço futuro. A razão para isto foi exógena, neste momento irrompeu a guerra na Líbia, fazendo com que, as condições no mercado físico fossem de encontro das condições antecipadas pelo mercado futuro. Neste período a reversão se deu pelo aumento dos preços físicos e não por uma queda nos preços do mercado futuro. Este período inclusive foi marcado pela liberação do estoque das Reservas Estratégicas Americanas (SPR), conforme ilustrado no gráfico 22.

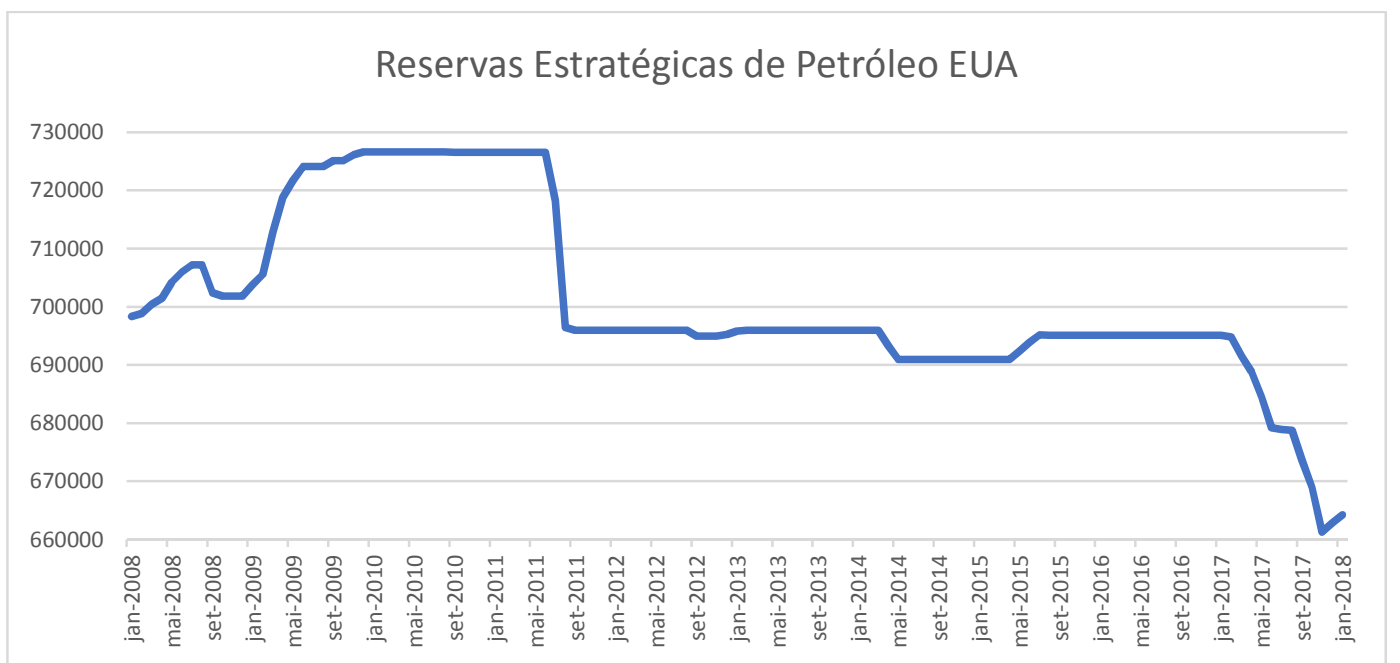

Gráfico 22: Volume nas Reservas Estratégicas do EUA

A principal razão para que o Índice de Pressão funcione é de que o mercado físico, por possuir efetivas negociações de petróleo baseadas nos fundamentos correntes, transmite sinais antecipados que somente se refletirão em períodos seguintes quando da divulgação de dados de fundamentos como, produção, estoque e demanda.

Os mercados futuros por sua vez, como não estão diretamente conectados à situação corrente de oferta e demanda e, por sofrerem influência de dados macroeconômicos e financeiros, demoram mais para refletir as relações de preços reais. 
$\mathrm{O}$ fato dos fundamentos de oferta e demanda correntes não se refletirem prontamente nos mercados futuros, advém da principal característica do mercado de Petróleo: As negociações de preços com base em diferenciais para benchmarks. O que o Índice de Pressão faz é, traduzir, com base nos diferenciais, se os fundamentos de mercado estão ficando mais fortes ou mais fracos em determinado tempo. Não levando em conta assim, o preço absoluto do petróleo, que é definido nos mercados futuros onde sofre influência de outros fatores no curtíssimo prazo.

Por exemplo, quando há um aumento da oferta de petróleo, o reflexo deste aumento de produção se dá no diferencial para um benchmark, pois é assim que o petróleo é negociado, sem que este aumento na oferta impacte o preço absoluto do benchmark. No momento seguinte, como houve uma queda de preço relativo, há um aumento da demanda pelas refinarias que, no período seguinte vai se refletir no aumento da oferta de produtos para o mercado. Neste movimento podemos notar que:

1- Há um aumento marginal da oferta de petróleo físico;

2- Há uma queda marginal de preço relativo do petróleo físico contra o benchmark;

3- Há um aumento marginal de demanda pelas refinarias, dada a queda do preço relativo;

4- Há um aumento marginal da oferta de produtos derivados;

5- Há uma queda das margens de refino, ou o acúmulo de estoque.

Neste exemplo, o mercado financeiro somente absorveria esta informação quando:

1- O aumento da oferta fosse divulgado, ex-post, por alguma agência de notícias ou órgão oficial de estatística;

2- Houvesse a divulgação de preços por alguma agência de reporte de preços;

3- O aumento do volume processado fosse divulgado, ex-post, por alguma agência de notícias ou órgão oficial de estatística;

4- $\mathrm{O}$ aumento do volume produzido de produtos fosse divulgado, ex-post, por alguma agência de notícias ou órgão oficial de estatística;

5- O acúmulo de estoque fosse divulgado, ex-post, por alguma agência de notícias ou órgão oficial de estatística. 
Desta forma, fica claro que, a mudança dos preços relativos dá sinais fortes do que está ocorrendo nos fundamentos de mercado correntes, antes que qualquer dado seja divulgado.

No período de 2016 e 2017, pôde-se notar, gráfico 23, como o Índice de Pressão aqui desenhado, forneceu informações antecipadas sobre os fundamentos do mercado, que posteriormente se refletiram nos níveis de estoques comerciais dos Estados Unidos, divulgados por sua agência de energia EIA, Energy Information Administration.

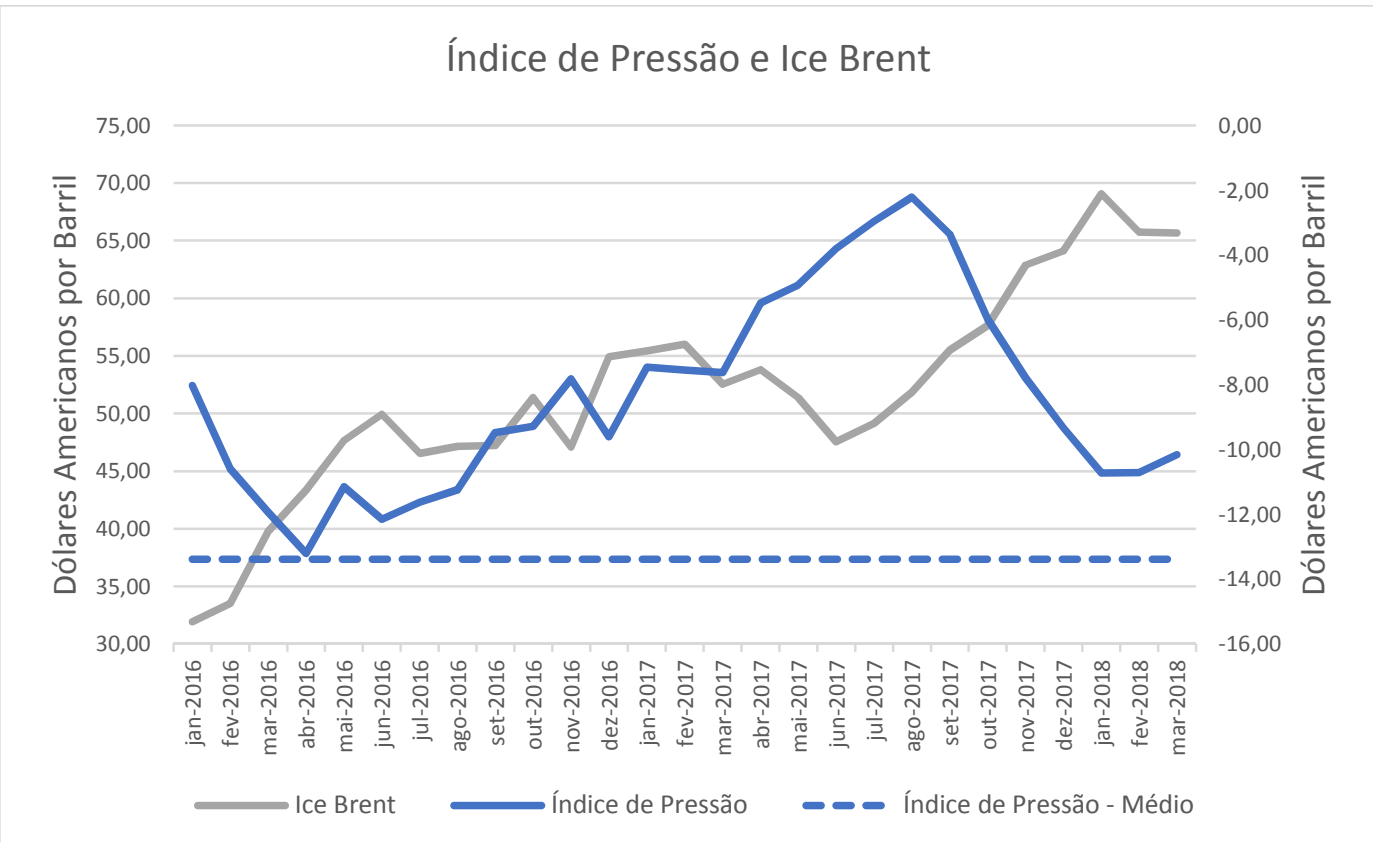

Gráfico 23: Reversão do índice de pressão para a média e aumento do preço do ICE Brent

Ainda no gráfico 23, o Índice de Pressão começou a mostrar em abril de 2016 que havia um descolamento do preço financeiro do físico, porém o efetivo movimento do preço do primeiro vencimento do contrato futuro do Ice Brent para um novo patamar somente ocorreu após sucessivas divulgações de queda no volume de estoques americanos, gráfico 24 , momento este em que o Índice de Pressão também iniciou sua reversão ao ponto, aqui definido, como sendo de equilíbrio. 


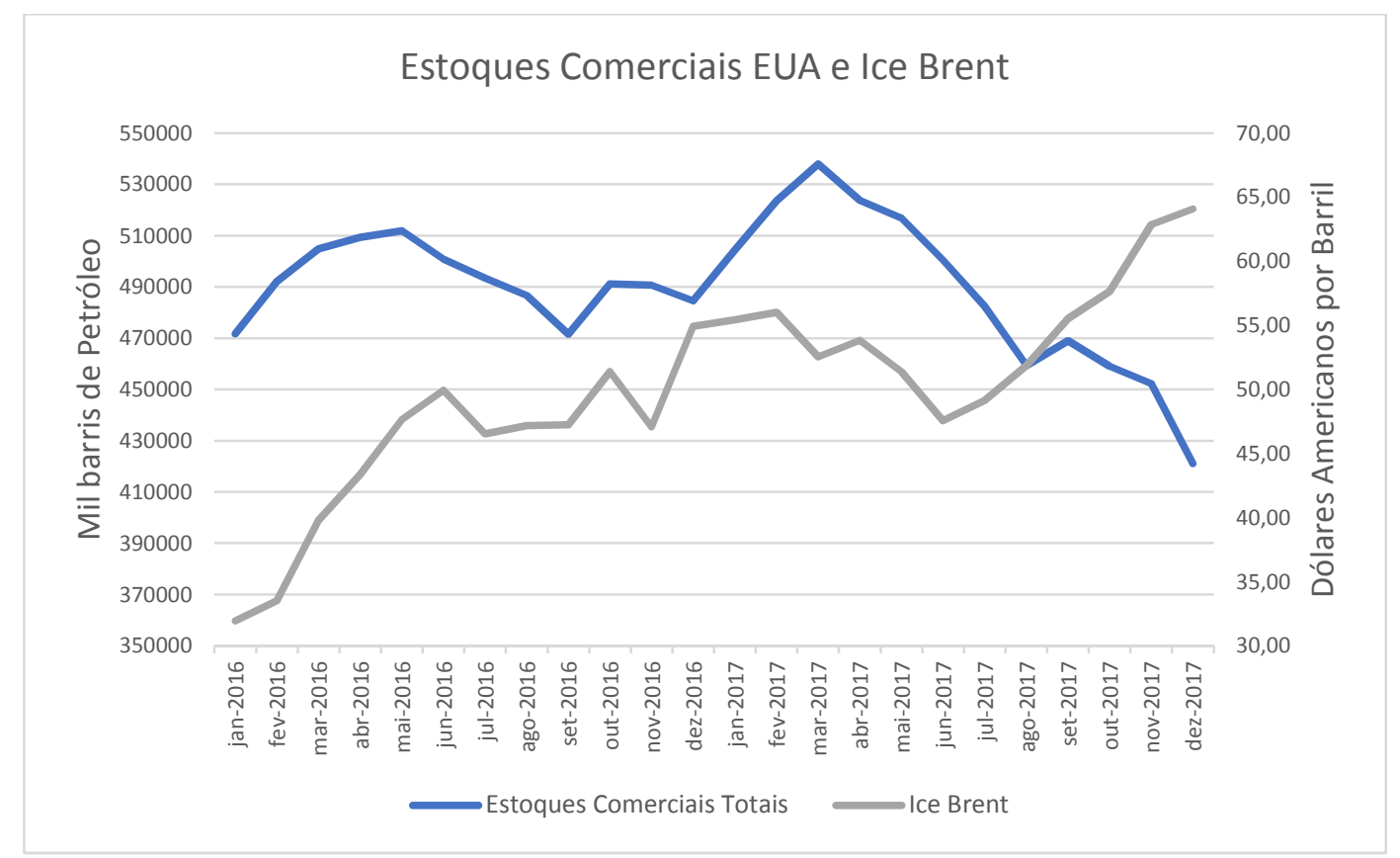

Gráfico 24: Queda dos estoques comerciais de Petróleo dos EUA e aumento do Preço do ICE Brent

Para ilustrar, se o preço do mercado futuro reagisse conforme os sinais de curtíssimo prazo do mercado físico, seu valor, no exemplo acima, subiria mais rápido e não geraria a distorção explicitada pelo Índice de Pressão. 


\section{6 \\ Conclusão}

A combinação dos diferenciais para a criação do Índice de Pressão pode de forma rápida e objetiva demonstrar as condições físicas do mercado de petróleo para um determinado período com relação a um benchmark. A descrição dos processos de descoberta de preços e como são formados os preços dos benchmarks faz com que surjam suspeitas de que há um descompasso entre os preços físicos e financeiros de petróleo.

O Índice de pressão torna estes descompassos explícitos, porém sua reversão à média mostra, como em períodos mais longos de tempo, há uma tendência à convergência dos preços. Portanto a pura análise das relações de preços explicitadas pelos diferenciais traz informações poderosas sobre as condições correntes do mercado. Não há uma completude de informações no índice, porém, a velocidade com que pode ser observado traz uma grande vantagem frente a análise de dados de fundamentos que em geral são absorvidas pelo mercado somente em períodos subsequentes. Podemos dizer que a divulgação dos dados é "notícia velha" pois a maior parte dos impactos que as informações irão gerar já foram precificados pelos agentes que transacionam o petróleo no dia-a-dia.

Por se tratar de um estudo qualitativo, para a introdução e definição do Índice de Pressão, testes quantitativos e análises estatísticas serão fruto de trabalhos futuros. A criação do índice abre um amplo espectro para pesquisas futuras. O debate com relação a eficácia dos benchmarks e a financeirização do mercado de petróleo ganha mais um instrumento. Algumas linhas de pesquisa que podem se seguir são a aplicação do índice de pressão para outros petróleos, mostrar o papel dos especuladores nos mercados futuros, a volatilidade no mercado de petróleo, aplicação do índice de pressão a modelos auto-regressivos para previsão dos preços de petróleo, entre outras. 
Principalmente, a criação do Índice de Pressão mostra como as forças do mercado nem sempre são traduzidas para o preço absoluto do petróleo, fazendo com que os sinais de preço para os agentes sejam, de tempos em tempos, passados de forma errada, o que pode gerar, em períodos subsequentes, maior amplitude para os ciclos de ajuste dos preços do petróleo. 


\section{Referências bibliográficas}

BARRET, C. Brent Prices: Impact of PRA methodology on price formation. Oxford Institute for Energy Studies, Oxford. 2012.

BOLETIM ANUAL DE PREÇOS 2014. Preços do petróleo, gás natural e combustíveis nos mercados nacional e internacional, Agência Nacional do Petróleo, Gás Natural e Biocombustíveis. ANP 2014.

DANIELSEN, A. L. The Evolution of OPEC. New York: Harcourt Brace Jovanovich. 1982.

FATTOUH, B. An anatomy of the crude pricing system. Oxford Institute for Energy Studies, Oxford. 2011.

. The Dynamics of Crude Oil Price Differentials. Energy Economics. n. 32, p. 334-342, 2010.

HORSNELL, P.; MABRO, R. Oil Markets and Prices: The Brent Market and the Formation of World Oil Prices, Oxford: Oxford University Press. 1993.

MABRO, R. On Oil Price Concepts. WPM3, Oxford: Oxford Institute for Energy Studies, Oxford. 1984.

METHODOLOGY AND SPECIFICATION GUIDE: CRUDE OIL, PLATTS, 2017

MIAO, H.; RAMCHANDER, S.; WANG, T.; YANG, D., Influential factors in crude oil price forecasting, Energy Economics. n. 68, p. 77-88, 2017

PARRA, F. Oil Politics: A Modern History of Petroleum, London: IB Tauris 2004.

RATS, M.; SERGEANT, A. The Power of Backwardation; Raising Oil Price Forecast to \$75. The Oil Manual, Morgan Stanley Research, January, 2018.

SEYMOUR, A. The Oil Price and Non-OPEC Suppl. Oxford Institute for Energy Studies, Oxford. 1990.

SKEET, I. OPEC: Twenty Five Years of Prices and Politics. UK: Cambridge University Press. 1988.

WOOLDRIDGE, J. M. Introdução à Econometria: Uma Abordagem Moderna. Cengage Learning, p. 711-712, 2016. 